Review Article 2019

\title{
Cuddapah Basin, India: A Collage of Proterozoic Subbasins and Terranes
}

\author{
VIVEK S KALE ${ }^{1, *}$, DILIP SAHA ${ }^{2}$, SARBANI PATRABNIS-DEB ${ }^{2}$, V V SESHA SAI ${ }^{3}$, VIKASH \\ TRIPATHY ${ }^{4}$ and SHILPA PATIL-PILLAI ${ }^{5}$ \\ ${ }^{1}$ Advanced Center for Water Resources Development and Management (ACWADAM), Pune 411 052, \\ India \\ ${ }^{2}$ Geological Studies Unit, Indian Statistical Institute, Kolkata 700 108, India \\ ${ }^{3}$ Geological Survey of India, Central Region, Nagpur 440 006, India \\ ${ }^{4}$ Geological Survey of India, Training Institute, Hyderabad 500 068, India \\ ${ }^{5}$ Department of Environmental Science, Savitribai Phule Pune University, Pune 411 007, India
}

(Received on 15 July 2019; Accepted on 25 September 2019)

\begin{abstract}
The sedimentary sequences and associated magmatic rocks from the Cuddapah basin and adjoining fold belts on the eastern margin of the Dharwar craton of Peninsular India are repositories of several economic mineral deposits, including radioactive mineral deposits. Growing evidence suggests that the array of subbasins (on the western side), the Nallamalai Fold Belt, and the eastern Nellore Schist Belt represent independent terranes that were tectonically connected. PaleoproterozoicMesoproterozoic extensional passive margin development with the attached oceanic realm, followed by Mesoproterozoic collisional tectonics and a subsequent Neoproterozoic extensional regime resulted in the present configuration of this region. A review of recent publications suggests that several traditional views deserve to be modified. This region needs to be examined in light of the emerging models of Proterozoic supercontinental assembly and break-up. Open areas of debate and gaps in confirmatory evidence for such models are discussed to provide directions for future studies.
\end{abstract}

Keywords: Cuddapah Basin; Sedimentary Sequences; Economic Mineral Deposits

\section{Introduction}

The crescent-shaped Cuddapah Basin (CB) spread across $45,000 \mathrm{~km}^{2}$, hosts the thickest of the Purana sequences (Meijerink et al., 1984; Nagaraja Rao et al., 1987; Kale, 1991). The absence of younger cover makes it an ideal Proterozoic basin for the unobstructed study of sedimentation patterns, interbedded volcanics and intrusive bodies, basement - cover relations, structural patterns and tectonic evolution. Subsequent studies on sedimentological, stratigraphic, structural, paleontological, and tectonic aspects have contributed to the current knowledge of this basin (Saha and Tripathy, 2012; Matin, 2015; Chakrabarti et al., 2016). Although traditionally considered either to be a part of the adjoining Mesoproterozoic Eastern Ghats mobile belt or an equivalent of the Archean Dharwar schist belts; recent studies of the Nellore Schist Belt (NSB) have demonstrated its close (structural and temporal) relation with the Nallamalai Fold Belt (NFB) in the eastern part of the CB (Chetty, 2001; Collins et al., 2015). Geophysical studies across this region (Misra and Ravi Kumar, 2013; Chandrakala et al., 2015) have been consistent in indicating that the continental crust below the CB and NSB is continuous, although dissected by the deep upper-crustal thrusts. We, consider them to be contiguous crustal blocks. This suggests that the CB, NFB and NSB are a collage of terranes separated by tectonic contacts that have an interlinked evolutionary history spanning the Late Paleoproterozoic to Neoproterozoic times (Tripathy et al., 2019; Saha and Sain, 2019).

We review the work done in the last 4-6 years on this collage of terranes located on the eastern margin of the Dharwar craton to enumerate the current state of knowledge. The easier access to sophisticated

*Author for Correspondence: E-mail: dr.vivekale@gmail.com 
analytical techniques, isotopic data, and higher resolution of multispectral remote sensing and geophysical data holds the promise of enabling an accurate, reproducible and robust understanding of the evolutionary history of the CB, NFB and NSB terranes than ever before. This cannot replace the foundation of basic field observations and highresolution data collection across the basin.

\section{Regional Framework}

The Cuddapah basin is an epicratonic basin located along the eastern margin of the Dharwar Craton of Peninsular India (Fig. 1). The Mesoarchean gneisses and schists of the Eastern Dharwar craton (EDC) intruded by Neoarchean granitic bodies constitute the basement of the $\mathrm{CB}$, collectively referred to as the 'Archean Basement Complex' (Ramakrishnan and Vaidyanadhan, 2008; Roy and Purohit, 2018). These crystalline rocks are intruded by at least two phases of mafic dykes during the Paleoproterozoic times (Kumar et al., 2015). The sediments from the Cuddapah basin display an angular and erosional unconformity with this basement all along its western boundary.

The NSB is thrust upon the sediments along the Vellikonda Thrust (earlier called the Nallamalai Thrust: King, 1872; renamed by Venkatakrishna and Dotiwala, 1987) which marks the eastern boundary of the CB including the NFB. The NSB has two components, namely the Udaigiri Group (in the south) and the Vinjamuru Group (in the north), that are in thrust contact with the NFB. The contact between the Udaigiri and Vinjamuru domains has been interpreted as a transpressive shear zone with the local occurrence of a slice of basement granite gneiss around Podili (Saha et al., 2015; Das et al., 2016). On its eastern side, the NSB has a tectonic contact with the southern part of the Eastern Ghats Belt (EGB), referred to as the Ongole domain.

The NSB is followed westward across the Vellikonda thrust by folded quartzites, slates and phyllites of the NFB, in general with very low-grade metamorphism, locally reaching biotite-grade. The Maidukuru Thrust (earlier called the Rudravaram Line) marks the western tectonic boundary of the NFB. West of this is a series of four subbasins that host relatively undeformed and unmetamorphosed sediments, namely the Palnad, Srisailam, Kurnool and
Papaghni subbasins from north to south respectively. The Palnad and Kurnool subbasins host Neoproterozoic sediments, while the Papaghni and Srisailam subbasins host Paleo- to Mesoproterozoic sediments. Given this tectonic configuration, it is time to recognize that this region is a collage of tectonic terranes, each with a different evolutionary history.

\section{Stratigraphy}

\section{Basement Complex}

The $\mathrm{CB}$ is floored by the granite-gneiss-greenstone terrain of the EDC (Fig. 1). Granite-granodiorite gneisses with N-S foliation and N-S to NNW-SSE oriented greenstone belts intruded by Neoarchean (2.6-2.5 Ga) granitic batholiths comprise the EDC (Mukherjee et al., 2018). Two phases of gneisses, (with the older ones having rafts of amphibolitic schists) from the EDC are often called the Peninsular Gneiss (Valdiya, 2016). The greenstone belts (e.g., Ramagiri, Kadiri, Veligalu, Tsundupalle) are metamorphosed volcano-sedimentary sequences having sheared mylonitised contacts with the Peninsular Gneiss. This milieu of crystalline rocks is intruded by several pulses of mafic intrusives during the Paleoproterozoic (between $\sim 2.37 \mathrm{Ga}$ and $\sim 1.89$ $\mathrm{Ga}$ ), which have been interpreted to have affinities to mantle plumes (Pandey and Chalapathi Rao, 2019).

These rocks from the EDC (including Archean gneisses and supracrustal schists, granitoid and mafic intrusives) are exposed on the west and north of the CB (Fig. 1) as its 'basement complex.' The Proterozoic sequences rest with an angular and erosional unconformity over this basement complex, which also serves as a provenance for the sediments.

\section{Cuddapah Basin}

The changes in the stratigraphy of the CB first given by King (1872) and modified by subsequent workers (e.g., Meijerink et al., 1984; Nagaraja Rao Rao et al., 1987) has been summarised by Patranabis-Deb et al. (2012: Table 1). Nagaraja Rao et al. (1987) gave an independent status to the Kurnool Group and separated it from Cuddapah Supergroup which included the Papaghni, Chitravati and Nallamalai Groups. However, the deformed Nallamalai Group in the NFB (excluding the Srisailam Quartzite) is shown to be allochthonous, bounded by major thrusts 


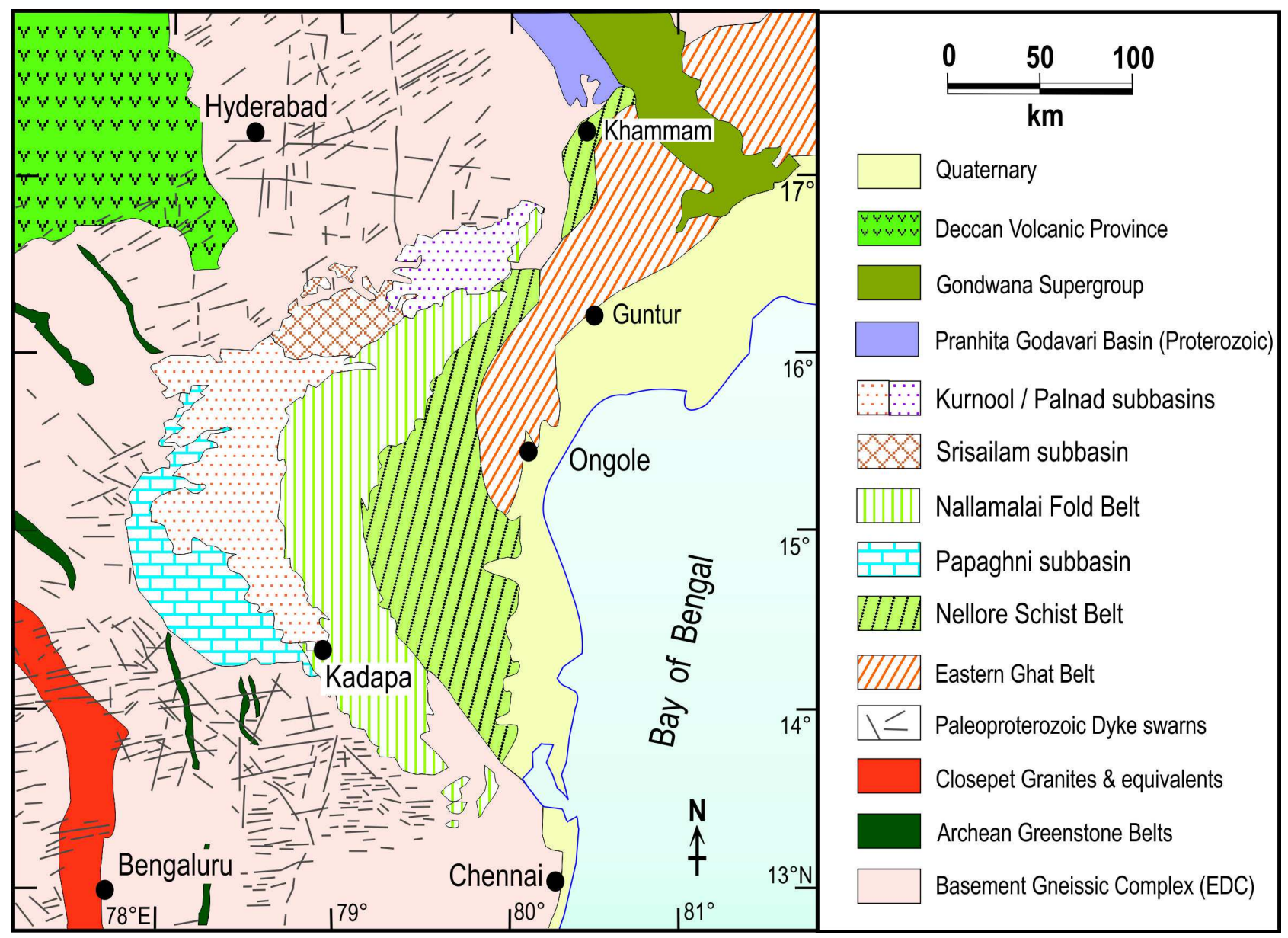

Fig. 1: Regional setting of the Cuddapah basin and adjoining terrains. The official spelling of the town 'Cuddapah' has been changed to "Kadapa."

(Tripathy et al., 2019) and advocated its exclusion from the Cuddapah Supergroup. This is reflected in Table 1 which enumerates the stratigraphy of this basin.

The Papaghni Group, Chitravati Group, and Srisailam Quartzite Formation are unconformity bounded sequences. The Papaghni and Chitravati Groups occur in an arcuate belt (recognized as the Papaghni subbasin) on the western margin of the CB (Fig. 2). The Nallamalai Group has tectonic contacts on either side. South of Kadapa town, the Bairenkonda Quartzite, is exposed resting with an angular unconformity on the Gulcheru Quartzite and shales from the Tadpatri Formation (GSI, 1981). This exposure demonstrates that the Nallamalai Group must be younger than the Papaghni and Chitravati Groups. However, there is a need to reassess the contact between the three groups from the perspective of the Maidukuru Thrust and the observations regarding the equivalence of Gandikota Formation (e.g., Meijerink et al., 1984; Tripathy et al., 2019).

The Srisailam Quartzite rests directly upon the Archean basement with an unconformity on the western edge of the Srisailam subbasin. It is capped unconformably by the Kurnool Group in the north, with local faulted contacts. It displays tectonic contacts with the Nallamalai Group, making it difficult to establish a firm stratigraphic order of superposition. Whether the Srisailam Quartzite is an undisturbed equivalent of some of the sediments from the Nallamalai Group or a younger independent sequence is a contentious issue (Saha and Majumdar 2012; Saha and Tripathy, 2012b; Patranabis-Deb et al., 2012).

The Neoproterozoic Kurnool Group rests unconformably on the other sequences of this basin, as well as the basement gneisses. The sediments of 
Table 1: Lithostratigraphy of Cuddapah basin and Nallamalai Fold Belt (compiled from GSI, 1981; Nagaraja Rao et al., 1987; with modifications by Saha and Tripathy, 2012;Patranabis-Deb et al., 2012). The order of superposition takes into account the relations between units discussed in the text

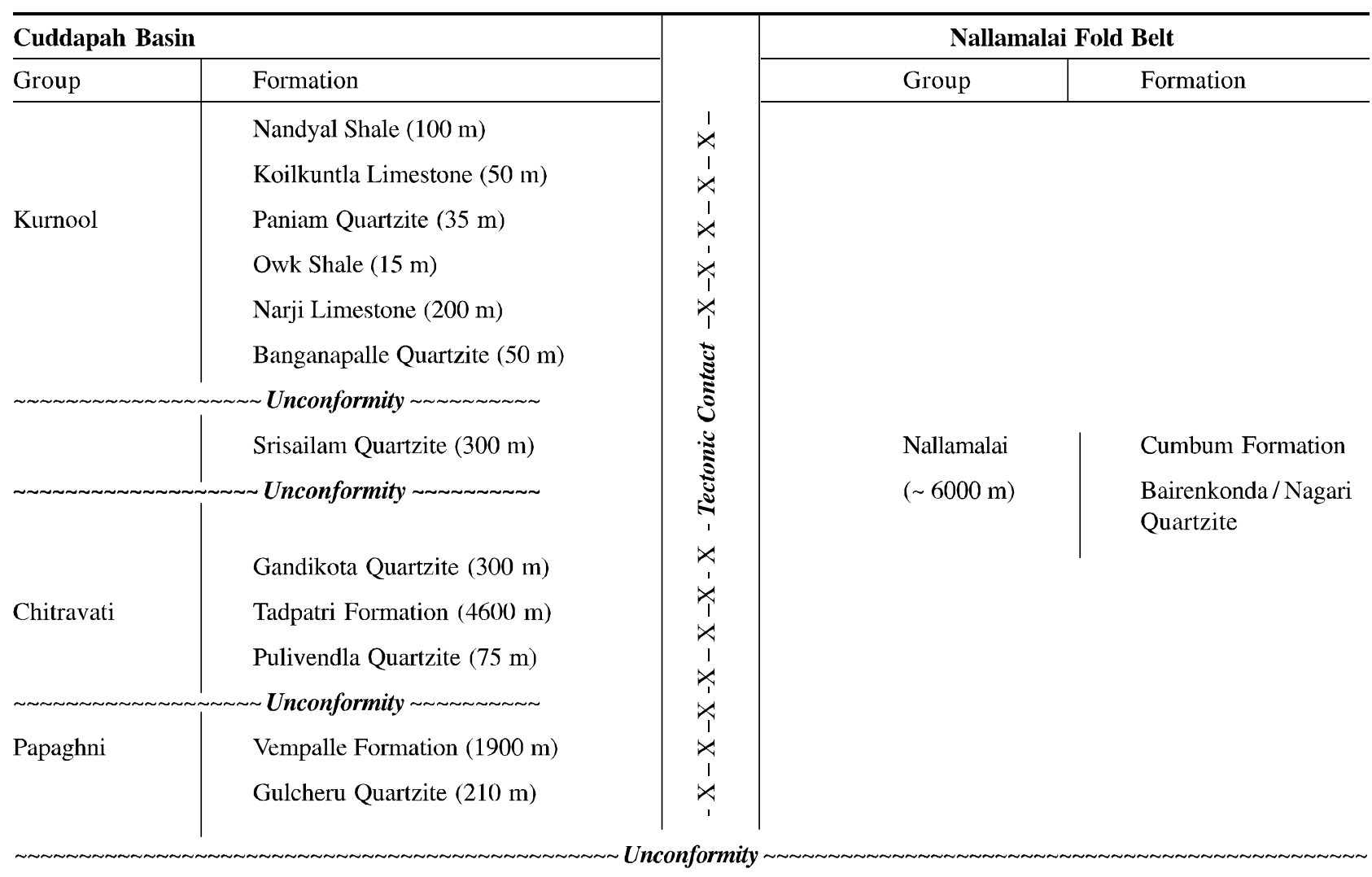

ArcheanGranite, Undifferentiated Peninsular Gneisses,

greenstone belts and Archean \& Paleoproterozoic basic dykes of EDC

this group were deposited in two subbasins detached from each other, namely the Kurnool and Palnad subbasins (Fig. 2).

\section{Nellore Schist Belt (NSB)}

The NSB is a composite tectonostratigraphic entity comprising greenschist facies to amphibolite facies volcano-sedimentary domains intruded by granitic and alkaline plutons, and small slivers of ophiolites (Fig. 3). Some previous authors have considered the schist belt exposed near Khammam, north of this N-S trending curvilinear belt, to be equivalent to it and described it collectively as the Nellore-Khammam Schist belt. Others considered it to be comparable to schist belts from the EDC. Ramam and Murty (1997) classified the NSB into the lower Vinjamuru Group and the upper Udaigiri Group. The Vinjamuru Group consists of migmatitic gneisses with patches of quartzites and metapelites (kyanite - staurolite garnet - quartz schists) intruded by mica-pegmatites. The Udaigiri Group is composed of chlorite - biotite schists and quartzites with cherty bands. Saha et al. (2017) have recommended that these two components of the NSB are better recognized as tectonic domains based on lithostratigraphic association, metamorphic grade and geochemical attributes.

The 1.25-1.40 Ga Prakasam Alkaline Province (PAkP), consisting of many granitic stocks and bosses as well as felsic to mafic alkaline rocks that intrude the NSB in its northern parts (Fig. 3) besides the adjoining gneissic basement. An accretionary terrane at Kanigiri $(\sim 1.33 \mathrm{Ga})$ in the central region and the $(\sim 1.89 \mathrm{Ga})$ Kandra Ophiolite Complex in the southern part of the belt add to the complex tectonic character of the NSB. The deformed rocks in the Kanigiri area have been interpreted as dismembered 


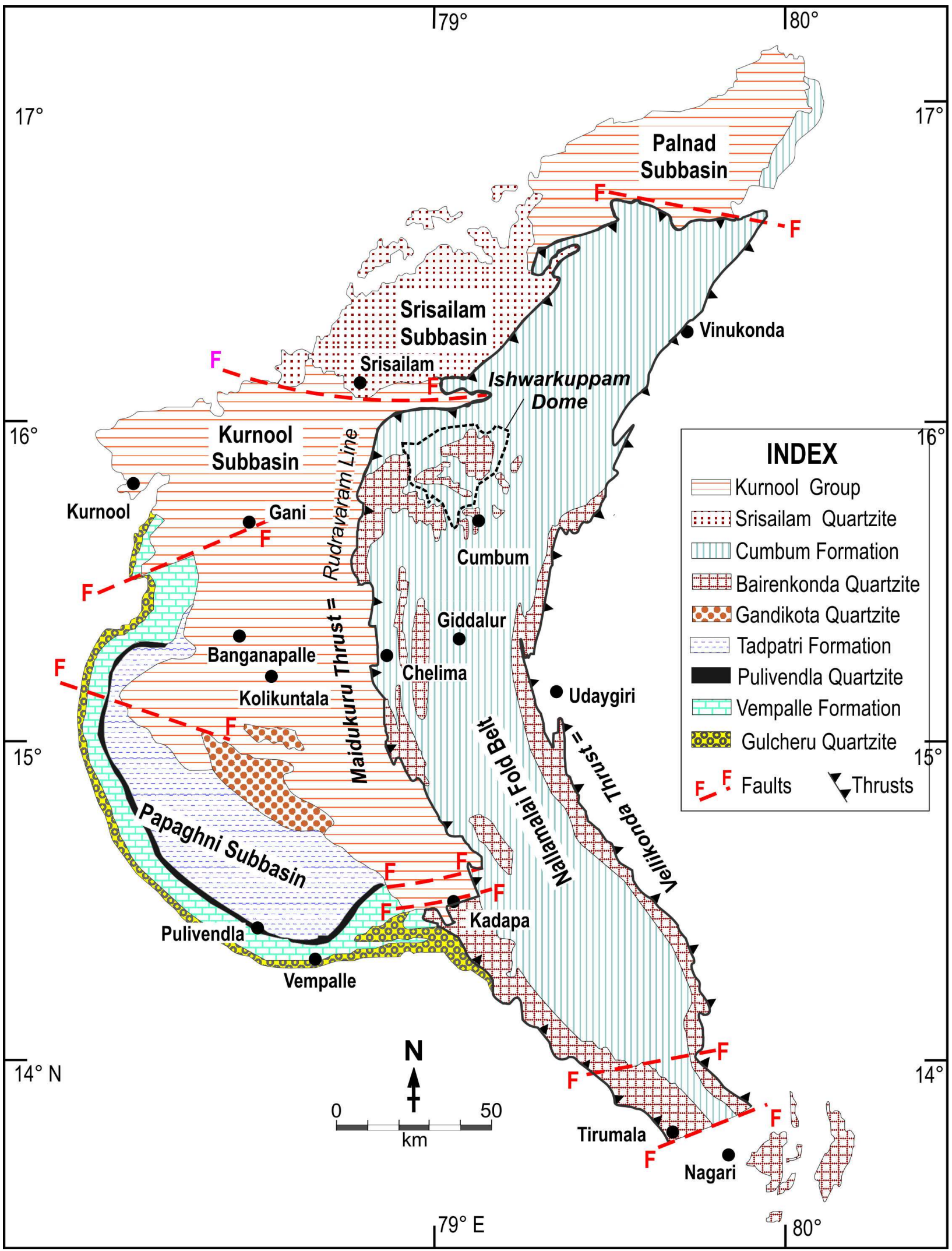

Fig. 2: Geological map of the Cuddapah Supergroup, Nallamalai Group, and Kurnool Group depicting the subbasinal configuration (compiled from various sources cited in the text). Given that all of them are floored by a common basement, they may be clubbed together (sensu: Allen et al., 2005; 2015) into a common basin (= Cuddapah Basin) 
Paleoproterozoic supra-subduction zone ophiolite with a melange zone (Sain and Saha, 2018).

\section{Sedimentation Patterns}

We summarise the sedimentary (with associated volcanics) contents from the CB, NFB, and NSB below. While doing so, a subbasin-wise description is given to ensure that the geographic context and tectonic settings are taken on board. Detailed sedimentological analysis of the intensely deformed and metamorphosed NSB as a whole is difficult and unavailable. The sediments in the Kandra Ophiolite Complex consist of psammo-pelitic shallow marine sediments, greywacke turbidite, matrix-supported conglomerate, and chert, with the deepwater association indicative of arc-trench system (Saha et al., 2017).

\section{Papaghni Subbasin}

This subbasin (occurring on the south-western corner) has been traditionally recognized to host the oldest sediments from the Cuddapah basin. Recent studies reaffirm this aspect. The older Papaghni Group ( $2110 \mathrm{~m}$ ) and younger Chitravati Group ( 4975 m) constitute the sequence exposed in this subbasin. These gently easterly dipping sequences are locally deformed along the faults that transect them. Both of them contain associated igneous rocks, in the form of mafic lava flows, ultramafic and mafic sills and felsic tuffs and rhyolitic bands interbedded within the sediments. The absence of metamorphic imprint (except local thermal alterations in the contacts with the dykes and sills) ensures that the sedimentological aspects of these sequences can be examined unhindered.

\section{Papaghni Group}

The Papaghni Group represents the first sedimentary cycle in the Cuddapah basin. It rests with anerosional unconformity upon the basement complex.

\section{Gulcheru Quartzite}

It is constituted of detrital siliciclastic sediments, represented by polymictic conglomerates, coarse (often pebbly) sandstones, and shales. The immature basal coarse-grained rudites pass upward into moderately well sorted medium-grained trough crossstratiûed glauconitic sandstone, which is succeeded by interlaminated sandstone-siltstones and eventually thinly bedded mudstones. The gradational upward transition from immature clasticrudites to finer siliciclastics indicates progressive maturation and peneplanation of the provenance.

The overall facies associations suggest a tectonically controlled alluvial fan system with episodic basement uplift and erosion during the basin opening stage (Mazumder et al., 2015). A prodelta phase and the passage to shelf bar-interbar deposits are attributed to the ensuing arenaceous and argillaceous sediments. The shallow scours pools mantled with ripple marks of diverse morphology suggest the development of intertidal flats and slow passage to the carbonate platform of the Vempalle Formation (Saha et al., 2016).

Goswami et al. (2017a) reported microbially induced sedimentary structures (MISS) in the Gulcheru Quartzite and inferred the facies association to be an alluvial fan to shallow marine shelf environment. Geochemical study of the mudstone from the Gulcheru Quartzite indicates both weathered and juvenile source simultaneously contributed sediments to the basin; and that they are compatible with those of the detritus derived from active continental margin to continental arc settings (Chakrabarti et al., 2016). Sesha Sai et al. (2016) proposed that the red, ferruginous beds from the Gulcheru Formation may represent the Paleoproterozoic oxygenation event $(\sim 2.1 \mathrm{Ga})$.

Taken together, the Gulcheru Quartzite manifests rapid lateral facies changes indicating briskly shifting depositional systems, variable rates of sediment influx, and uneven rates of subsidence and creation of accommodation in different parts of the subbasin. It is indicative of the early growth and progressive deepening of a continental margin basin from an alluvial fan to a shallow marine setting.

\section{Vempalle Formation}

It displays a gradational contact with the underlying Gulcheru Quartzite. It consists of alternations of cherty dolomites, stromatolitic dolomite, and shale, with sandstone and chert beds occurring interbedded within them. Mafic lava flows, sills/dykes and a few tuffaceous horizons are encountered within this Formation. Cross-stratification, flaser beddings, faded 
ripples are commonly observed in the sandstone, near the contact between the Gulcheru and the Vempalle Formations (Saha et al., 2016; Bose et al., 2017). Tepee structures and desiccation cracks filled with lime mud or fine sands, molar tooth structures and rhombic halite cast (Phansalkar et al., 1991) have been recorded from the laminated shale indicating events of subaerial exposure and local evaporitic environments.

Dolomite and oolite bars point to intertidal to the subtidal origin, while laminated shales with halite casts point to shallow sabkha sedimentation in an arid climate. The rich assemblage of stromatolitic bioherms is well known from the Vempalle dolomites. Changing the pattern and style of the stromatolites reflect the depth partitioned growth of the microbial community (Bose et al., 2017; Patranabis-Deb et al., 2018). They are attributed to a low angle ramp type carbonate platform. The $(\sim 2000 \mathrm{~m})$ thick accumulation of carbonates on this platform, with local and temporary variations in the depositional milieu, suggests that sedimentation and relative rise of the sea-level kept pace with each other over a significant period. Such platforms are characteristics of passive margin basins.

Soft sediment deformation structures, intraformational limestone breccia beds (Fig. 5c) are known from several segments of the Vempalle succession (Panja et al., 2019). Large scale slump structures are observed in the distal part of the carbonate platform, suggesting the onset of basin-floor instability leading to the cessation of sedimentation on this platform. The demise of the platform is marked by the deposition of thick brown shale with laterally persistent beds of chert in the uppermost parts of the Vempalle Formation (Goswami et al., 2015).

Meter-thick lavas, sills and thinner dykes of basalt and/or dolerite occur in the upper part of the Vempalle Formation (Nagaraja Rao et al., 1987; Anand et al., 2003; French et al., 2008). They are named as Kuppalapalle Volcanics. Asbestos and gypsum deposits have been mined from the contacts of the Vempalle sills in the past (Srikantia, 1984). Some of the richest uranium deposits have been discovered from the area around Tummalapalle (Vasudeva Rao et al., 1989; Jeyagopal et al., 2012) from the Vempalle dolomites.

\section{Chitravati Group}

The Chitravati Group unconformably overlies the Papaghni Group, and represents the second cycle of sedimentation inthe Cuddapah basin. It is subdivided into the Pulivendla Quartzite, Tadpatri Formation and Gandikota Quartzite in ascending order and is intruded by several mafic sills and dykes at various stratigraphic levels.

\section{Pulivendla Quartzite}

It consists dominantly of medium-to-thick bedded quartz-arenite with pebbly sandstone and conglomerate in the basal part. They contain clasts derived from the underlying Papaghni Group, indicating that some of the beds of the Papaghni Group were exposed to erosion during the deposition of these beds. Conglomerate beds are laterally impersistent, and have been inferred to represent mass-flow (washed colluvial) deposit, of an alluvial fan system with ephemeral streams.

The quartz arenite beds are trough- or planar cross stratified or plane parallel stratified, deposited in a delta front. These mineralogically mature sediments indicate recycling (Saha et al., 2016) and are likely to have been deposited along the shore-line, at or very close to the sea-level. Bedding planes display symmetric to slightly asymmetric sinuous to straight crested ripples with tuning fork bifurcation. Some of the ripple-marked bedding planes preserve desiccation cracks, and some with well-rounded granule lag in the troughs. Conglomerates occur as impersistent lenses, while the quartz arenite show strikes continuity across the Papaghni sub-basin. Bipolar, bimodal palaeocurrent directions have been recorded from the Pulivendla Quartzite. These beds can be continuously traced across long distances along their strike, further indicating their deposition along a sandy shore-line under the influence of long-shore and tidal currents. Somasekhar et al. (2018) have inferred that these siliciclastics have been derived from an Archean crust and deposited in a passive margin environment based on their chemical characterisation.

\section{Tadpatri Formation}

It is dominated by shales, followed by sandstone and dolomite. The shale overlies Pulivendla Quartzite with a sharp contact, grades up into sandstone-mudstone 
heterolithics, with several units of stratified sandstone and stromatolitic dolomite, forming coarsening and thickening up the succession. Persistent parallel planar lamination and paucity of interbedded sandy units point to the deposition of the shales in an outer shelf environment below normal wave-base. The appearance of sandstone beds with planar- and wavyparallel lamination, and low angle hummocky- and swaley cross-stratiûcation indicates localized and temporary shallowing of the depositional interface, within the storm wave base. The dolomitic units commonly show algal laminites and stratiform stromatolites. The coarsening- and shallowing-up succession suggests a relative sea-level fall and a significant regression from outer-shelf to inner-shelf environments in a storm- and tide-dominated environments. Mitra et al. (2018a) recently studied the stromatolites in the upper part of the Tadpatri Formation in six different stratigraphic sections. Based on the variations in the bioherm geometry, they inferred a supratidal to the subtidal depositional environment for the carbonates from this formation. Mitra et al. (2018b) concluded that the clastics were derived from deeply weathered felsic source rocks and that the shales were deposited in an oxic environment.

Several dolerite sills and basaltic lava flows are present within the Tadpatri Formation (Chakraborty et al., 2016). Chilled margins of the dolerite and contact metamorphic effect in the host carbonates are commonly seen. Studies indicated that the $1.9 \mathrm{Ga}$ ultramafic sill (Anand et al., 2001) in the lower part of the Tadpari Formation mineralogically varies from olivine gabbro norite to plagioclase bearing ultramafic rocks (Sesha Sai et al., 2017). Goswami et al. (2018) have recorded the presence of bimodal volcanics and tuffs within the Tadpatri Formation.

\section{Gandikota Quartzite}

Has a gradational contact with the underlying Tadpatri Formation. It is dominantly constituted of thick-bedded quartzose sandstone. This $300 \mathrm{~m}$ thick quartzite unit exposed along the walls of the Pennar river gorge section was described by King (1872) as the "Scarp sandstones" based on its occurrence along the nearly vertical escarpments.

The sandstone consists mostly of medium- to coarse-grained, well-sorted and well-rounded quartz- and feldspathic arenite. Oppositely oriented cross stratified beds, HCS beds and massive beds with local abundance of mud flakes occur throughout the succession. A variety of wave ripples with straight or bifurcated crests and different types of interference patterns which commonly mantle shallow swash pools, are prolific in the upper beds of the formation. Spindleshaped linear and polygonal shrinkage cracks on the bedding surfaces suggest a shallowing of the environment, with intermittent exposure. On the whole, this quartzitic sandstone can be attributed to having been deposited in tide and storm dominated open shelf environment.

Earlier workers (e.g., Meijerink et al., 1984: p. 69 described an angular unconformity between these sandstones and the underlying Tadpatri shale) had mapped the Gandikota Quartzite as the undeformed beds of the Nallamalai Group, exposed west of the "Rudravaram Line" (= Maidukuru Thrust). Nagaraja Rao et al. (1987) demonstrated that this unit must be recognized as the youngest unit in the Chitravati Group. This argument was supported bythe subsequent work and Saha and Tripathy (2012) and Patranabis-Deb et al. (2012). As discussed later, there are further additional doubts raised on the age and correlation of the Gandikota Quartzite in light of the detrital zircon ages which indicate a Mesoproterozoic age to it (Collins et al., 2015), while the rest of the Chitravati Group is certainly Paleoproterozoic.

\section{Nallamalai Subbasin}

The Nallamalai subbasin is a tectonically defined (rather than sedimentologically) segment of the CB, bounded on either side by the Maidukuru and Vellikonda Thrusts (Fig. 2). The sedimentary sequence within this subbasin is pervasively folded (as described below) and affected by anchizone to lower greenschist facies metamorphism. This makes the recognition of the vertical stratigraphic sequence in this subbasin ambiguous. As an example, while the distinction between the Nagari and Bairenkonda Quartzite (Table 1) is ambiguously defined several exposures (including those attributed to the Srisailam and Gandikota Formations: as depicted in Fig. 3) have been considered to be undeformed equivalents of the Bairenkonda Quartzite. Further, some sandstone beds that have been mapped by earlier authors as Bairenkonda Quartzite (particularly in the 


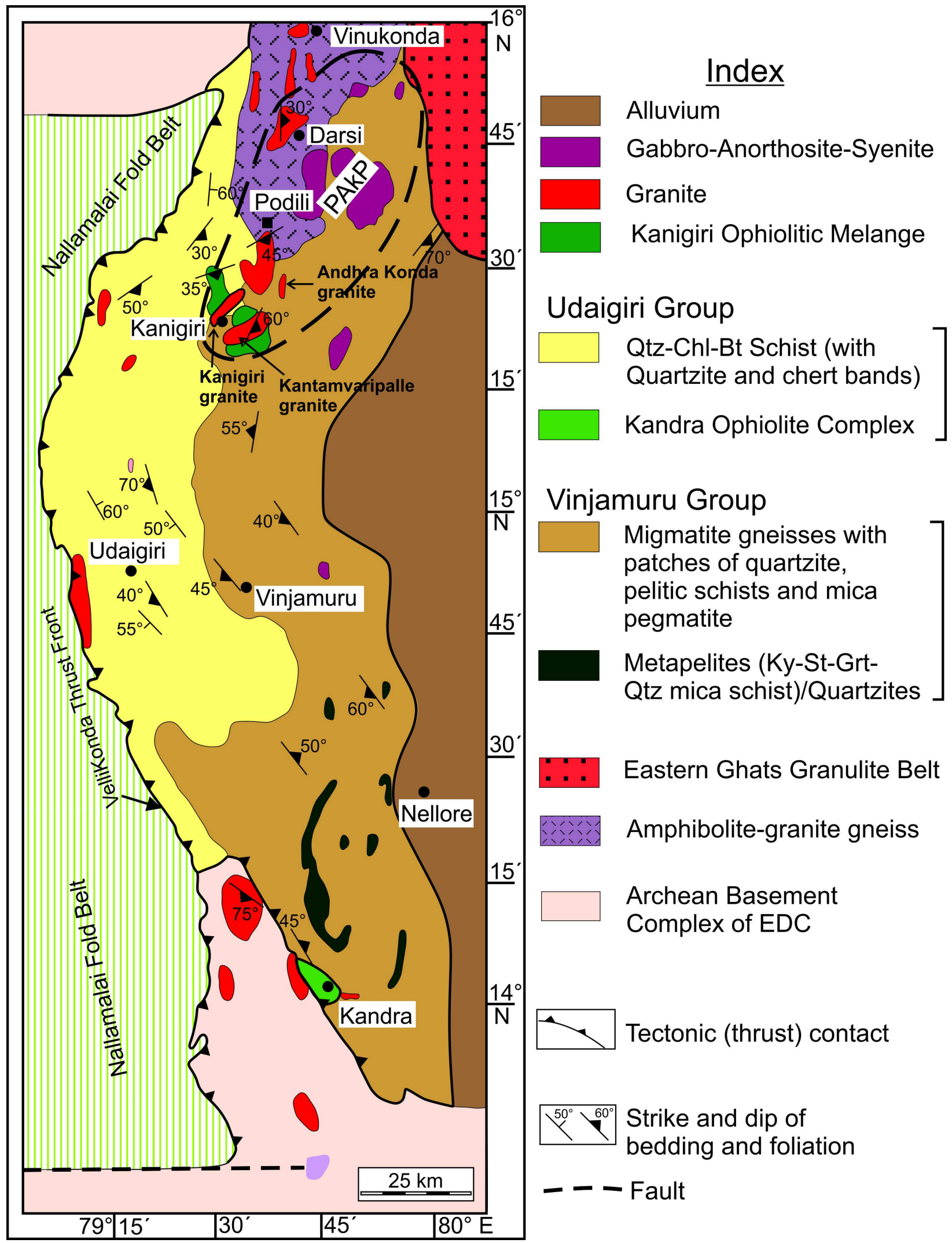

Fig. 3: Geological map of the Nellore Schist Belt (modified after Srinivasan and Roop Kumar, 1995; by Saha et al., 2017; Sain and Saha, 2018) showing the distribution of intrusive granites, alkaline complex (Prakasam Alkaline Complex - PAkP is shown with a dashed outline) and ophiolite slivers 
Ishwarkuppam dome) appear to rest upon the shalelimestone sequence of the Cumbum Formation. This problem will be best resolved, once the geometry of the folded NFB is appropriately documented and the lateral continuation of beds established across the folds and faults. Significant observations in this context are recorded by Meijerink et al. (1984); Saha (2002, 2004); Chetty (2011); Tripathy and Saha $(2013,2015)$ and Tripathy et al. (2019).

\section{Nagari/Bairenkonda Quartzites}

The unconformable relation between this formation and the underlying Chitravati Group of sediments is best examined in the road section between Vempalle and Kadapa. As discussed by Nagaraja Rao et al. (1987), the Nagari and Bairenkonda Quartzites occur at the base of the Nallamalai Group in the southern and northern exposures, respectively. Saha et al. (2016) do not differentiate between them and consider them to be lateral equivalents of each other (but with different names in different locations). The Ishwarkuppam dome (see Fig. 2) is considered as the type exposures of the Bairenkonda Quartzite, while the folded quartzitic ridges (occurring in the southern part of the NFB, between Tirupati and Kadapa) are called the Nagari Quartzite.

Both these thick sequences of quartzites display the presence of thin impersistent beds and lenses of pebbly conglomerates and gritty sandstones at the base, followed by thickly bedded quartz-rich sandstones with siltstones and shales interbedded within them. At places, glauconitic sandstones have been recorded from this sequence. Across most of the exposures (in the fold belt) the rock displays significant recrystallization with sutured grain boundaries. Few primary sedimentary structures such as a variety of ripple marks, intercalated lenses of mudstones displaying mudcracks and tabular crossbedded can be recognized from these quartzites. In the area around Dornala, a thick sequence of shales (comprising siliceous siltstones and purple ferruginous shales) with a pervasive slaty cleavage is presently interbedded within the quartzitic sandstones. Some beds within this slaty horizon (termed as Dornala Slate in literature) displays evidence of having suffered softsediment deformation.

These sediments can be attributed to a shoreface environment, ranging from supratidal to the beach environment. Saha et al. (2016) have suggested that they are a product of a deltaic fan system which eventually grades to a peritidal to inner shelf environment of deposition.

\section{Cumbum Formation}

Deformed sediments that were mapped by earlier authors as Pullampet (Kolamnala) Slate, Giddalur Quartzite, and Dolomite are collectively included within this Formation. The arenaceous Bairenkonda Quartzite is followed upwards with a gradational contact by siliceous and ferruginous argillites of the Cumbum Formation. Initially thin interbeds within the basal conglomerates and sandstones give way rapidly to progressively thicker and thicker shales of this formation. The argillites grade into calcareous shales and dolomitic limestones further up in the sequence. Stromatolitic colonies have been recorded from several places in the dolomitic limestones. These stromatolitic assemblages are established to be of Riphean age. This sequence of the Cumbum Formation generally occupies the valleys that alternate with the quartzitic ridges in the NFB. These rocks display ductile deformation. Recent studies have shown that some of the 'porcellanite' beds and cherty beds interbedded within this shale-limestone sequence are either ash-fall tuffs or recycled volcaniclastic deposits. Based on their overall characters, these sediments are attributed to an initial barrier beach environment that rapidly is replaced by tidal flats. Inner to outer shelf regime dominates in the middle part of this formation (with thick dolomites and calcareous shale) which eventually gives way to the subtidal bar to peritidal environments in the upper parts.

These rocks have been subjected to low-grade metamorphic alterations at places, with maximum biotite grade metamorphism being recorded in the pelitic rocks. Chlorite schists, chloritic quartzites and incipient hypersthene development in the impure calcareous rocks have been recorded from different parts of the NFB.

\section{Srisailam Subbasin}

The Srisailam subbasin is separated from the Papaghni subbasin (that hosts the older sequences in the CB) by the cap of younger sediments in the Kurnool subbasin (Fig. 2). Its western edge exposes the angular and erosional unconformity below which the basement 
complex rocks are exposed. Its eastern contact with the NFB is unconformable at places and tectonic at others. The spectacular $150-225$ m deep Krishna river gorge runs across this subbasin across a channel length of nearly $100 \mathrm{~km}$. This subbasin hosts only the Srisailam Quartzite.

\section{Srisailam Quartzite}

This is a $300 \mathrm{~m}$ thick sequence of quartzose sandstone with a very high degree of mineralogical maturity. Ferruginous sandstones (red-beds) and minor shales (including some horizons of black shales) are also present. Large cosets of tabular cross strata indicate that they were deposited by part of a large river system, deposited in dominantly arid, barren conditions. Wave ripples and dunes, with the concentration of very well-sorted and well-rounded coarse sand and granules in the troughs, are recorded on the bedding planes of thicker beds. The braided alluvial deposits are followed by mature marine sandstones and some beds that suggest aeolian deposition (Patranabis-Deb et al., 2012). The topmost beds in succession consist of quartz arenites, represent deposition in wave-dominated environments where constant winnowing operated. The sandstones form positive-relief sand-bodies, which are made up of "wavy parallel" or "pinch and swale" beds, creating shoaling up linear bars and ridges, separated from each other by muddy to low-energy sandy deposits.

The occurrence of red-beds within this sequence has been interpreted to suggest that it was deposited after the Great Oxidation Event (GOE) in an essential fluvial to the marine environment, which includes proximal to distal reaches of braided alluvial plains under conditions of lateral migration of the active river system. Basu et al. (2017) recognized five facies associations (containing fifteen individual facies) of sandstones and black shales from the Chitrial outlier of the Srisailam Quartzite. They suggested continental half-graben type basin with the black shales and sandstones being attributed to a deep lacustrine and pro-delta environments respectively. Prolonged vertical aggradation in a gently subsiding intracratonic depository led to the formation of the thick units of the Srisailam subbasin without any major break.

\section{Kurnool and Palnad Subbasins}

The Kurnool Group is developed in two subbasins, the Kurnool in the west-central part and the Palnad in the north-eastern part of the Cuddapah Basin (Figs. 1 and 2) The Kurnool Group in Kurnool subbasin, overlies the Papaghni and Chitravati Groups and onlaps the gneissic basement of EDC with a major unconformity. In Palnad area the Kurnool Group unconformably overlies the Peninsular Gneiss and the Srisailam Quartzite. The Kurnool Group is more than $450 \mathrm{~m}$ thick and is divided into six formations, comprising two cycles of sandstone - limestone shale sequences in the Kurnool subbasin (Table 1).

\section{Banganapalle Quartzite}

The Banganapalle Quartzite rests upon the basement complex with an unconformity along the western edge of the Palnad subbasin and the north-western edge of the Kurnool subbasin. It also displays an angular and erosional unconformity with the underlying sediments from the Srisailam and Papaghni subbasins, respectively (Fig. 2). The basal polymictic conglomerate contains a variety of clasts including those of red, green jasper, silicified dolomite, black or grey chert, vein quartz, quartzite, phyllite and granite. These basal rudaceous beds display normal or reverse grading of the clast sizes, and are internally crudely planar parallel stratified. They are laterally impersistent and grade upwards into coarse-grained pebbly sandstone. This is followed by multistorey bodies of trough cross-stratified coarse-grained sheet sandstones (with unidirectional south and east-ward palaeocurrent directions). They are attributed to alluvial fan and braided fluvial plain deposits. Crossstratified, medium-grained pebbly quartzose sandstone and well-sorted subarkosic to quartzose sandstone with bimodal-bidirectional palaeocurrent direction that follow, are petrologically more mature. These upper sandstones are interpreted to be deposited as tidalbars which gained height and experienced subaerial exposure. The upward fining succession in this formation displays increasing occurrence of mudstone drapes, suggesting a transgressive shoreline during a rise in relative sea level.

\section{Narji Limestone}

The plane laminated heterolithic siltstone-calcareous shale in the uppermost Banganapalle Quartzite gives way to laterally persistent beds of limestone marl of the Narji Limestone. These limestones occur in a subhorizontal disposition and are widespread in their 


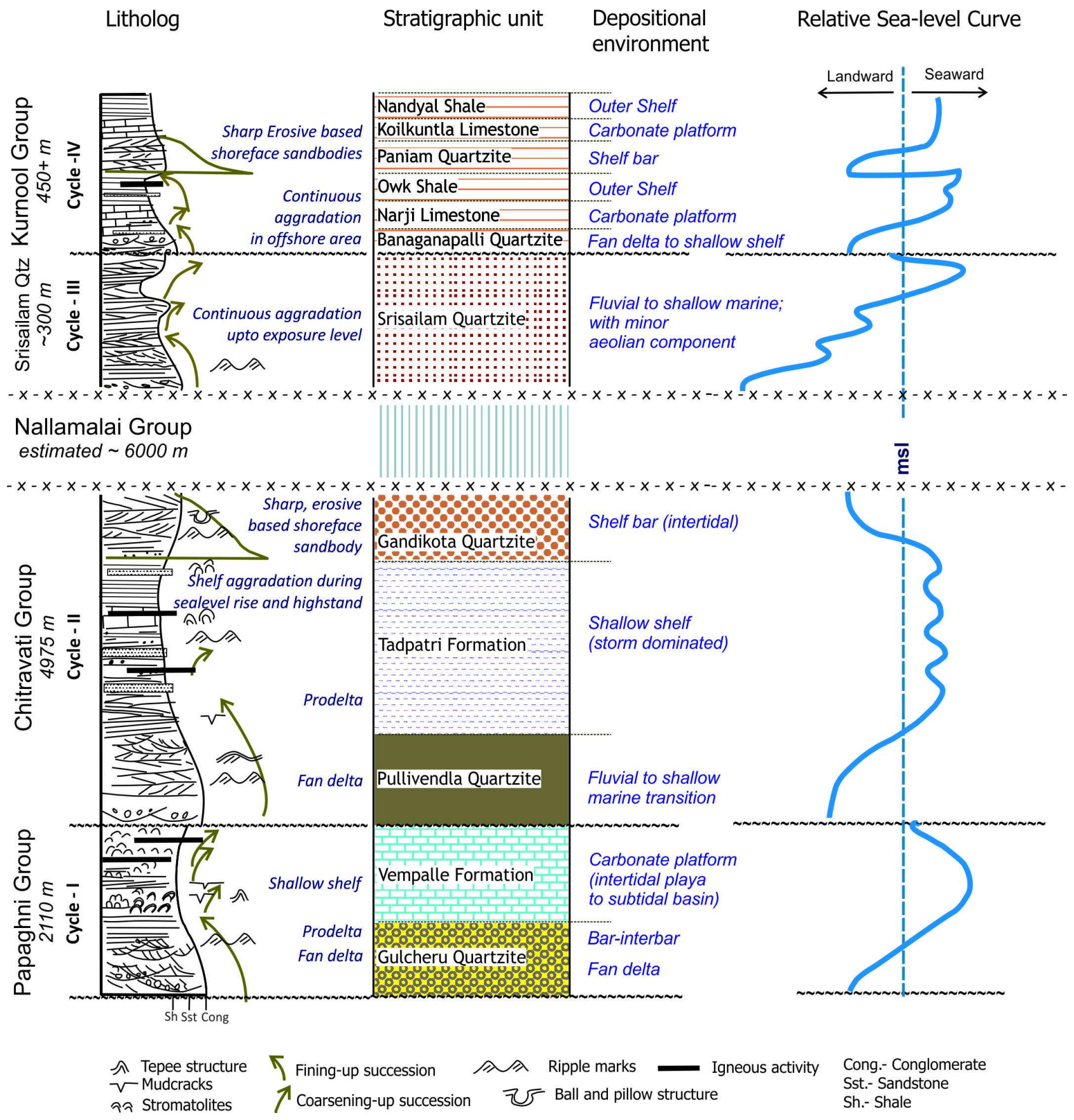

Fig. 4: Composite log of the Cuddapah Supergroup (excluding details of Nallamalai Group) showing the major constituents, their depositional environments, and the interpreted relative changes in the sea-level. Note, the lithological log is not to scale but is essentially intended to depict the major sedimentary units. The symbols in the third column are the same as in the map (Fig. 2) and are intended to provide a quick link to the distribution in space of these rocks.

presence across the Kurnool and Palnad subbasins. In the latter, this represents the youngest horizon that is exposed on the surface. Stromatolitic bioherms have been sporadically recorded from this horizon (Raha and Sastry, 1982).
The Narji limestones display a flaggy appearance, and beds can be traced laterally across several kilometers continuously. They generally display a rhythmic repetition of variegated and grey impure limestones in parallel stratified sequences. Such rhythmites suggest alternating cycles of climatic 
changes or alternating cycles of variations in the depositional environment. Presence of pyrite in some of these beds indicate a local euxinic condition that may reflect an oceanic anoxia (Patranabis-Deb et al., 2016) or episodic development of trapped seawater pools yielding locally reducing conditions. Such situations are common in the land-ward part of the maximum flooding surface during a transgressive cycle, where the basin is connected to the open ocean.

\section{Owk Shale}

The ochre yellow colored Owk Shale is laterally extensive across the Kurnool subbasin. This formation has a few interbedded fine sandy/silty beds in the upper parts. Welded tuff and volcaniclastic sandstones have been recorded at certain stratigraphic levels within the Owk Shale (Saha and Tripathy, 2012b). The shale beds are planar tabular and are internally plane parallel-laminated or exhibit normal grading. They may be interpreted to be tidal flat deposits in an outer shelf regime. Replacement of the relatively deepwater, carbonate platform by the muddy shelf depositing Owk Shale points to the lowering of the sea level.

Several carbonaceous organic remains and cyanobacteria have been reported from this horizon (Sharma et al., 2016; Sharma and Singh, 2019). Of these, Chuaria and Obruchevella have been considered to be diagnostic of upper Neoproterozoic age and suggest the correlation of the Kurnool Group with the comparable biota from the Bhima, Vindhyan and Chattisgarh basins.

\section{Paniam Quartzite}

The transition of the succeeding sandstones with the underlying the Owk Shale is marked by thin, wavy bedded to rippled, medium-grained quartzite, which passes up to very well sorted medium- to fine-grained quartz arenite (with 99\% quartz clasts). King (1872) named these sandstones as "Plateau Quartzite" or "Pinnacled Quartzite" based on their exposure as flattopped and steep pinnacle-like isolated hills around Paniam village in the Kurnool district.

The quartzose sandstone has $(>1 \mathrm{~m})$ thick parallel or lenticular beds that display internal wavy parallel or planar and trough cross-stratified nature with large foresets. The texturally and mineralogically mature sandstones with amalgamated cross-stratified beds are interpreted to be the products of wave reworked bars in an open coastal environment. The sharp contact between the Paniam Quartzite and the underlying shales, suggests a forced regression within the Kurnool subbasin.

\section{Koilkuntla Limestone}

Buff to mauve colored argillaceous limestone, devoid of any coarse clastic and stromatolite, and mostly composed of micrite and marl characterize the Koilkuntla Limestone. It overlies the Paniam Quartzite with a gradational contact. It is followed by the Nandyal Shale with a transitionalzone of argillaceous limestone. Laterally persistent, planar tabular beds with planar or wavy parallel laminations are conspicuous. This limestone also has micrite-marl rhythmites that persist across a few hundred meters laterally with a consistent thickness.

\section{Nandyal Shale}

Brown colored, thin-bedded, plane parallel laminated shale (with calcareous shales attaining a thickness of up to $15 \mathrm{~cm}$ ) overlying the Koilkuntla Limestone with a gradational contact is designated as the Nandyal Shale and best exposed near the Nandyal town. The storm laid thin $(1-2 \mathrm{~cm})$ normally graded silt or fine sand layers, often with fading ripple, are preserved in thicker shale beds. The coarser fraction represents the intermittent storm within muddy background sediments. Soft sediment deformation and lime-clast conglomerate beds are commonly seen in these beds.

\section{Synthesis}

Several earlier workers have analyzed sedimentary facies associations, their lateral and vertical distribution within the different subbasins from the Cuddapah Basin. We use the newer data and analysis to update this. Figure 4 summarizes the current understanding of the sedimentological patterns and the depositional regimes as enumerated in the preceding pages. We do not include the Nallamalai Group, pending a better resolution of its structural patterns leading to a more robust understanding of its succession and facies distribution.

The Cuddapah Supergroup consists of four unconformity bounded sequences. Each of these sequences appears to have a unique internal 
configuration, which reflects varying patterns of the relative sea-level change. Based on chemistry and stable isotopes, Khelen et al. (2017) and Mitra et al. (2018a) concluded that the Mesoproterozoic stromatolitic dolomites from the Vempalle and Tadpatri Formations were deposited in subtidal-intertidalsupratidal zones on a shallow shelf under warm, alkaline and anoxic conditions, in conformity with the sedimentological studies elucidated above. The variations in the relative sea-levels reflect not only differing rates of basin-floor subsidence driven by diversity in the tectonic environment in which it occurred but also the changes in the sediment supply from the provenance. The relative sea-level curve plotted in Fig. 4 (comparable to the exercise by Patil Pillai and Kale, 2019) is based purely on changes in the inferred the depositional depths of various horizons from the individual sequences.

The weathering in a humid subtropical climate and erosion of the Eastern Dharwar Craton occurring on its western side has supplied the terrigenous sediments for the Papaghni, Chitravati, Srisailam and Kurnool sequences (e.g., Collins et al., 2015; Khan et al., 2018). Detrital zircon analysis confirms the dominance of the EDC as the original primary provenance for the $\mathrm{CB}$, although some derivation from the Krishna Orogen as well as the Antarctic block has been indicated in the Nallamalai Group.

Palaeocurrent directions have changed with time. The Gulcheru Quartzite displays an easterly, north-easterly to south-easterly palaeoflow. The oolitic beds in the upper Vempalle Formation show northeasterly palaeocurrent directions. This may have been caused by the orientation of the oolite bank/bar in a direction transverse to the shore-line. The Pulivendla Quartzite preserve very strong north-easterly flow, but also with a weak opposite current, which may reflect the retreating tide. Gandikota represents overall north to northeast flow. Srisailam represents west to north-westerly flow. Banganapalle indicates south and easterly palaeoflow pattern with local bidirectional palaeocurrent.

\section{Structure and Tectonics}

The difficulties in decoding the structural complexities of the CB-NSB block (as enumerated quite aptly by King, 1872, and subsequent workers) were eased by the advent of remote sensing technology. The work of Meijerink et al. (1984), Venkatakrishna and Dotiwala (1987), Nagaraja Rao et al. (1987) and mapping by the officers of the Geological Survey of India (documented mostly in unpublished reports) and the Atomic Minerals Directorate demonstrate the efficacy of this technology in deciphering the structural complexities, leading to a more robust correlations of strata over the years. The District Resource Map series and Quadrangle Geological maps of the Geological Survey of India provide a glimpse of the exhaustive work by the officers of the Geological Survey of India in this basin, which unfortunately has remained excluded from the modern scientific discourse due to difficulties in accessing their work. The overall structural framework of this region has been enumerated above Regional Framework.

\section{Tectonic Subdivisions}

The following sequence of geologically and structurally distinct domains can be recognized along an E-W regional traverse across the Cuddapah basin (Fig. 5). They are also evident in the Deep Seismic Sounding profiles across the basin:

(a) EDC: The deeply weathered and eroded cratonic block which has the Archean gneisses, greenstone belts, and granitoid bodies intruded by multiple pulses of Paleoproterozoic mafic dyke swarms.

(b) Western subbasins: Unconformable capping of gently eastward dipping Paleo- to Mesoproterozoic sedimentary sequences with interbedded igneous rocks (in the Papaghni and Srisailam subbasins) and subhorizontally disposed Neoproterozoic sedimentary sequences (of Kurnool Group). They are locally folded into open folds and drag folds along transverse faults and their eastern thrust boundaries.

(c) NFB: a Pervasively folded sequence of Mesoproterozoic sediments with essentially N$\mathrm{S}$ trending curvilinear regional fold axes; that is thrust over the sedimentary successions of western subbasins along its western edge.

(d) NSB: Neoarchean metavolcanics (Ravikant, 2010) with Mesoproterozoic accretionary sequences collisional arc affinities, ophiolite slivers, tectonic slices of basement gneisses, and intruded by granitic and alkaline bodies; which 


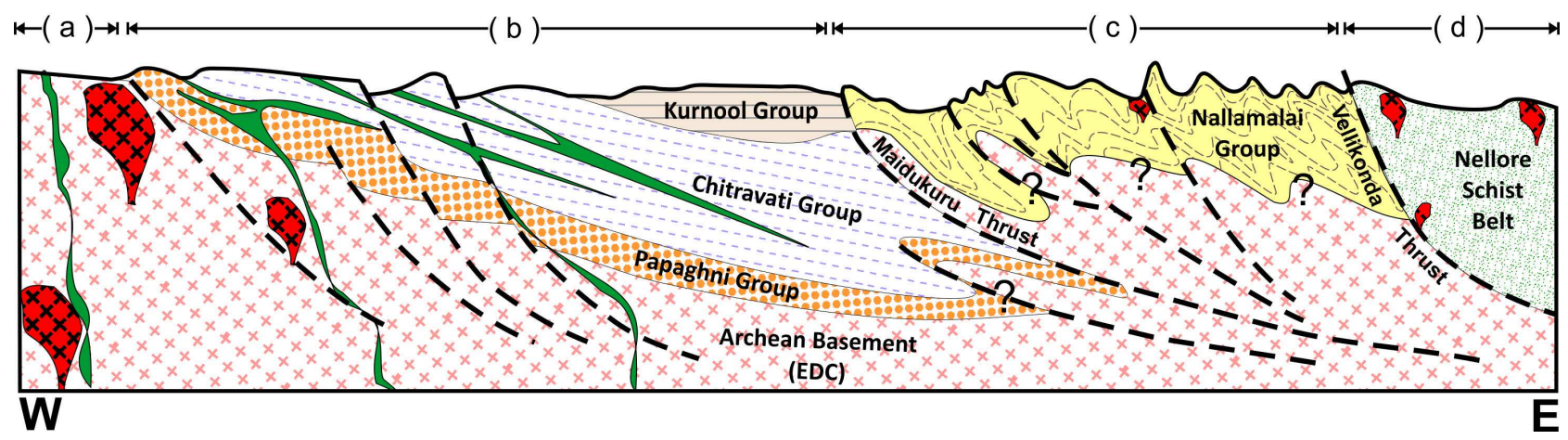

Fig. 5: Schematic E-W cross-section (not to scale) across the Cuddapah basin, modified after Johkan Ram (2012) based on field data, geophysical data and information discussed in the text above. The tectonic terranes that can be recognised are (a) Basement Terrain of the EDC, (b) Western subbasins, (c) Nallamalai Fold Belt and (d) Nellore Schist Belt from west to east successively. The granitoid intrusives (red blobs with crosses), mafic dykes / sills, and lavas (in green shading) and the faults associated with the Cuddapah Supergroup are depicted only in an indicative manner. See text for discussions on them

in turn is thrust over the NFB.

Geophysical studies across the CB since those in the 1980's by NGRI (e.g., Kaila and Tewari, 1985; Krishna Brahmam et al., 1986; Krishna Brahmam, 1989; Ram Babu, 1993; Kishore and Rama Rao, 2004) and more recent studies by Chandrakala et al. (2013) also show that these four adjoining terranes have a contiguous upper continental crust with mutually differing crustal characters. These studies also reaffirm the deep crustal nature of the Maidukuru and Vellikonda Thrusts that bound the NFB on either side and some of the other associated faults. Figure 5 is a generalized sketch of these terrains and their mutual relations and draws from the trans-basin sections compiled by several previous authors (King, 1872; Narayanaswami, 1966; Rajurkar and Ramalingaswamy, 1975; Nagaraja Rao et al., 1987; Kale, 1991).

\section{Basement}

As described above, this is the eastern margin of the East Dharwar Craton of southern India, which evolved through a series of events during the Archean times. This was subjected to a protracted period of weathering and erosion, leading to a peneplain topography capped by an extensive regolith layer after its emergence as a cratonic block. The relicts of this regolith horizon are preserved below the basementcover unconformity at several places along the western margin of the CB. Intrusive Neoarchean granitic bodies appear as tors and smooth rounded hillocks throughout the basement terrain.

Other than its inherited structural complexities, Paleoproterozoic intrusive mafic dyke swarms (Kumar et al., 2015; Nagaraju et al., 2018; Pandey and Chalapathi Rao, 2019) with preferred orientations and numerous regional quartz-pegmatite veins and dykes criss-cross the EDC. All these intrusives stand out as long linear ridges within the peneplain basement.

\section{Western Subbasins}

These sets of subbasins that host Proterozoic sediments along the western side of the $\mathrm{CB}$ are characterized by a structurally undeformed nature. The older sequences (Paleoproterozoic Papaghni - Chitravati Groups and Srisailam Group) display gently easterly dipping strata, while the younger Kurnool sequences display a dominantly subhorizontal disposition. The subbasins expose some extensional growth faults (of ten parallel to the subbasin boundaries) that are mostly normal gravity faults. Reverse faulting, drag folds (within the Papaghni Group) and steepening of strata are recorded along such faults, which have led to the repetition of strata in the down-dip direction. They suggest short-lived (?synsedimentary) tectonic events in the early history of the CB.

The sequences in these subbasins are transected by younger transverse faults (such as the Gani-Kalva fault), of which the major ones are depicted in Fig. 2. They strike in either the WNW-ESE or ENE-WSW direction. Transtensional deformation witha local 


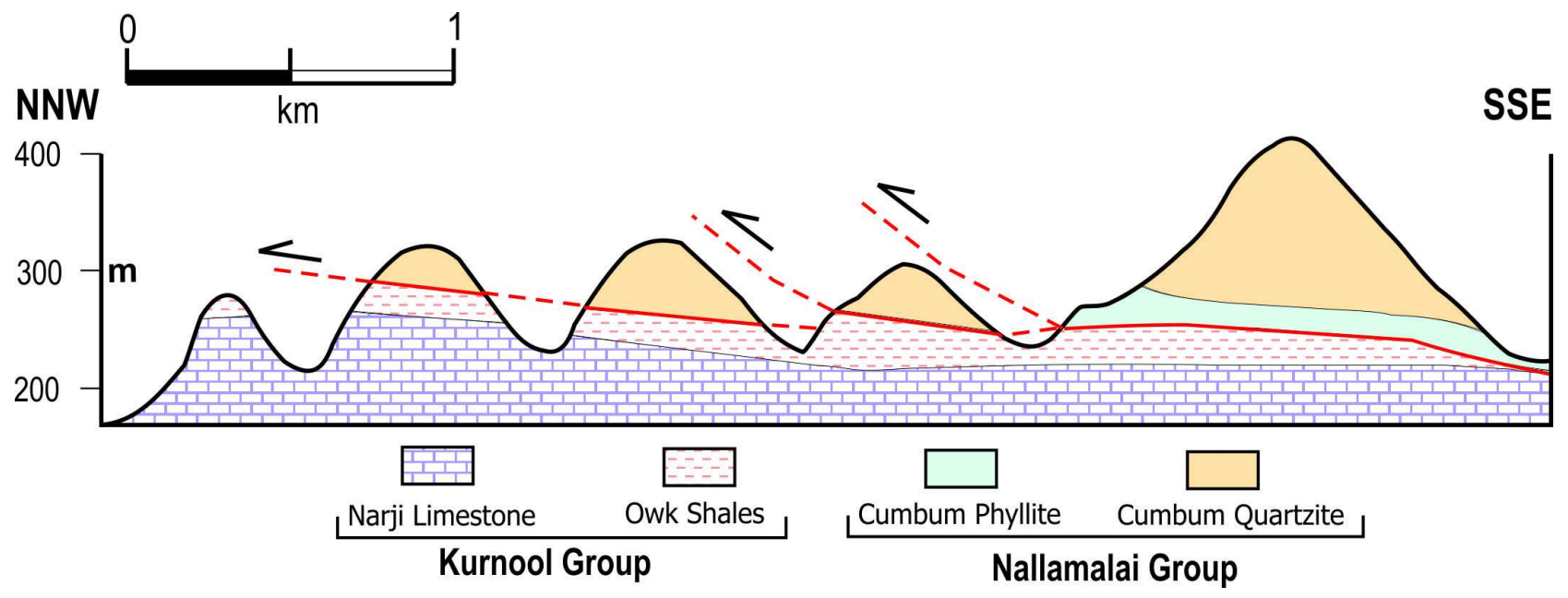

Fig. 6: Schematic geological cross-section showing the thrusting of deformed Nallamalai Group over the Kurnool Group. Note the schuppen structure within the NFB and development of klippe, west of Kakirala village, Guntur district, Andhra Pradesh

reverse sense of movement along the fault-plane is recorded from such transverse faults. They may represent the conjugate pair of extensional fractures that evolved during the E-W oriented opening of the CB. Recent studies in K.K. Kottala-Pulivendla section in the SW part of the basin, revealed the presence of NNW-SSE and ENE-WSW trending vertical fractures in the Gulcheru Formation. The former trend correlates well with the NNW-SSE to NNE-SSE trending mafic and ultramafic sills in the Papaghni sub-basin, suggesting that they were deep crustal fractures that acted as conduits for the magma emplacement. The sequences display intense cataclastic deformation in the sandy horizons and quasi-ductile deformation in the argillites and carbonate beds along with the Maidukuru thrust marking the eastern limit of the subbasins (both in the hanging wall and the immediate footwall). Structural analysis of the E-W trending faults such as the Vempalle and Idupulapaya faults from south of Papaghni subbasin (Goswami et al., 2016; Mukherjee et al., 2018) indicate that they are superimposed faults. Paleostress analysis of such late faults and joints from the basement and sedimentary cover from this part of the basin led to the inference of their origin linked to the EGB orogeny.

None of the sequences in these subbasins has suffered any significant metamorphic effects, except for thermal alterations along the walls of the intrusive sills in the Vempalle and Tadpatri Formations.
Cataclasis is recorded only in the vicinity of faults.

\section{Nallamalai Fold Belt (NFB)}

Field-based studies in recent years have contributed to deciphering the structural complexities of the NFB (Tripathy and Saha, 2010, 2015). Detailed mapping on a 1:25,000 scale in the northern part of the NFB, yielding significant evidence of its structural evolution concerning the Palnad subbasin. Tripathy et al. (2019) were able to demonstrate that the folded Nallamalai Group of rocks are thrust over subhorizontal Kurnool sediments. The complex folding and imbricate thrust planes could be modeled by them, providing an insight into the thrust-sheet emplacement along the Maidukuru Thrust. The thin-skinned nature of the thrust-sheet is evidenced by the development of klippe and window structures (Fig. 6).

Two events of thrusting can be recognized from the NFB. The thrusting of the Neoarchean granitic gneiss and the NSB along the Vellikonda Thrust (marking the eastern edge of the NFB) and of the Nallamalai Group on the relatively undeformed sequences from the western subbasins along the Maidukuru Thrust have produced the complex structural geometry of the sequence in the NFB. These structural patterns testify to the fact that this fold belt is an allochthonous unit, produced during a collisional tectonic regime (Saha and Sain, 2019). Recent studies on intrusive granitic rocks near Vellaturu, Ipuru and Nakerikallu from the NFB 
confirm that they are arc-magmatic intrusives. This collisional event may be related to the amalgamation of the Mesoproterozoic supercontinent. The various structural fabric recorded along the NFB suggest multiple events of convergence and extension with different stress regimes operating at different times in different parts of the belt.

The development of lower greenschist facies metamorphism, has been recorded in the NFB. The occurrence of chlorite-muscovite quartzites, chlorite schists, calc-silicate marbles, is known from various exposures of the Nallamalai Group. They can be related to the supra-crustal stress regimes that these rocks suffered during the multiple phases of thrusting.

\section{Nellore Schist Belt (NSB)}

Multiple cycles of deformation and metamorphism have affected the NSB. The Kandra ophiolite complex, occurring in the southern part of the NSB, hosts deep-water pelagic cherts, turbidites and intercalated pillowed metaba salts with sheeted dykes. This complex and associated high-grade metamorphic rocks from the Vinjamuru Group (Fig. 3) is considered to be 1.9 Ga old (Vijaya Kumar et al., 2010, Saha and Sain, 2019). A younger Kanigiri ophiolitic melange $(\sim 1.3 \mathrm{Ga})$ occurs in the northern parts of the NSB. Intensely folded meta-sedimentary rocks constitute the NSB as a whole, with the higher grade migmatitic gneisses and amphibolite grade metamorphics clubbed into the Vinjamuru Group, while the greenschist grade mica-schists and quartzites are clubbed in the Udaigiri Group.

Structurally and metamorphically, the NSB represents the upper crustal segments of a subduction zone complex, associated with island-arc development and closure. The closure of the oceanic realm and overthrusting of this block was associated with lower crustal melting that led to the emplacement of a large number of alkaline-granitoid intrusive bodies in the thrust sheets. These include the PAkP; Kanigiri, Kantamvaripalle, Podili, Vinukonda granites that were emplaced within the NSB; and also perhaps the Vellaturu-Ipuru-Nakerikallu granites emplaced within the NFB (Sesha Sai et al., 2017; Singh et al., 2018; Saha and Sain, 2019; Sesha Sai, 2019).

\section{Igneous Activity}

The Cuddapah Basin and its adjoining terrains have witnessed several phases of magmatism (GSI, 1981; Nagaraja Rao et al., 1987; Chatterjee and Bhattacharjee, 2001; Anand et al., 2003; Kumar et al., 2015) some of which are unequivocally linked to the tectonic evolution of this basin. We exclude the magmatic-metamorphic-anatectic phases that have contributed to the Archean cratonic evolution of the EDC and related basement complex from this discussion. These phases may be broadly classified (based on location, age and type) into:

a) Mafic dyke swarms intruding the EDC exposed west of the $\mathrm{CB}$;

b) Igneous rocks (including basaltic lava flows, mafic sills \& dykes, and tuffaceous volcaniclastic sediments) interbedded within the Cuddapah Supergroup;

c) Ophiolitic strata from the NSB;

d) Granitic and Alkaline igneous rocks intruding the NFB and NSB.

\section{Mafic dyke Swarms}

Paleoproterozoic mafic dykes intrude the basement complex of the EDC (Kumar et al., 2015; Nagaraju et al., 2018; Pandey and Chalapathi Rao, 2019). Based on their ages, five intracontinental tectonothermal events (at 2.37, 2.21, 2.18, 2.08, and $1.89 \mathrm{Ga}$ ) have been recognized to have manifested in these dykes. Kumar et al. (2012) inferred the swarm around 2.37 Ga to have an outward radiating geometry with the Clospet Granite massif - Western Dharwar craton at its center, Kumar et al. (2015) suggested that the $2.08 \mathrm{Ga}$ swarm seemed to radiate outwards from the CB.

Ophitic textures and serpentinized olivine (suggesting low-temperature alterations) are commonly recorded from them. These dykes are doleritic to gabbroic and are petrologically demonstrated to have been sourced from mantlederived melts. Some authors attribute them to thermal plumes, while others doubt such a model. Nonetheless, it is significant that the youngest of these dykes were coeval with the igneous activity interlayered in the Papaghni and Chitravati Groups.

\section{Interbedded Igneous Rocks}

They include a variety of lava flows, mafic sills, and 
intrusive dykes, occurring conformably interbedded within the sedimentary strata from the Papaghni subbasin. The presence of rhyolitic to rhyodacitic tuffs was recorded from the Owk Shale by Saha and Tripathy (2012b). No igneous rocks are known to be interbedded within sediments in the other parts of the basin. Suspected volcaniclastics interbedded within the Nallamalai Group and volcanogenic cherts in the limestones of Kurnool Group are potential exceptions to this statement, awaiting confirmation from future studies.

Chakraborty et al. (2016) had attributed partial melting of spinel - garnet peridotite for Vempalle lava flows. Singh et al. (2018) studied six basaltic lava flows from the Vempalle Formation. They suggested sulphur-saturated nature of magmas in a riftcontrolled intraplate setting associated with an oceancontinent transition zone for the emplacement of these lava flows based on PGE chemistry. Chakraborty et al. (2016) distinguished five varieties of sills intruding the Tadpatri Formation based on petrographic and geochemical studies. They inferred that the mafic sills of Tadpatri Formation are derived from small scale localized melting of the contaminated mantle in a rift setting. A small plume at depth may have initiated incipient rifting in western $\mathrm{CB}$, followed by partial melting of upper mantle according to them. Goswami et al. (2018) focused on the characterization and categorization of field-based features diagnostic of silica-rich volcanic activities and volcanic facies analysis in the Tadpatri Formation. They concluded that this volcanism was associated with rifting and was erupted in shallow marine condition. Lakshminarayana et al. (2019) inferred that the intrusive mafic bodies exposed north of Veldurti reflect the magmatic underplating at shallow crustal levels below the rifted western margin of the Cuddapah basin. Available dates of these mafic igneous rocks indicate that they were emplaced between $1.9 \mathrm{Ga}$ and $1.8 \mathrm{Ga}$, contemporaneously with the youngest dyke swarm intruding the basement of the $\mathrm{CB}$.

Taking the sedimentation patterns in the Papaghni subbasin and these igneous rocks into account, there is no doubt that it is an extensional continent-margin basin (sensu: Allen et al., 2015) that was associated with thermal activity. Whether a retroarc continental setting (Sesha Sai et al., 2017) or a rift-margin setting is more appropriate for this subbasin is a debate that is open as yet.

\section{Ophiolitic Rocks From NSB}

The Kandra Ophiolite Complex ( $1.9 \mathrm{Ga})$ and the Kanigiri accretionary terrain $(\sim 1.3 \mathrm{Ga})$ are exposed in the southern and northern parts of the NSB, respectively (Fig. 4). The slices of Kandra ophiolite complex and associated deep water pelagic chert and turbidites intercalated with pillowed metabasalts and sheeted dykes thrust within the amphibolitic schists and gneisses of Vinjamuru Group are interpreted to be remnants of oceanic back-arc crust (Saha and Sain, 2019). It has been suggested that the (arc-) oceanic realm in which they originated was at some distance from the eastern edge of the EDC before being tectonically transferred to their present location as imbricate thrust sheets. The development of granulite facies metamorphism and partial melting at $\sim 1.6-1.7 \mathrm{Ga}$ in the Ongole domain further east of the Vinjamuru domain probably indicates a culmination of Paleoproterozoic subduction-collision cycle on the east of the CB and NSB.

The existence of an island arc-type oceanic realm $\sim 1.3 \mathrm{Ga}$ east of the EDC is suggested by the fragmentary evidence preserved in the Kanigiri Ophiolite (KO) with a melange zone (Sain and Saha, 2018). It is speculated that the tectonic collapse of this volcanic arc with continued convergence onto the continental crust (which was fronted by the NFB) led to the amalgamation of the arc along with the Vinjamuru and Udaigiri domains. This collisional tectonism may be associated with partial crustal melting and emplacement of granitic and alkaline intrusives in this region.

\section{Granitic, Alkaline and Mafic Intrusives}

These include the various intrusive bodies recorded from several parts of the CB and NSB. As mentioned earlier, large batholithic granitic intrusives of Neoarchean and early Paleoproterozoic age in the EDC represent the last phase of cratonisation (Ramakrishnan and Vaidyanadhan, 2008). They do not prima-facie have a direct bearing on the evolution of the CB and its tectonics. Large granitic batholith emplacement in upper crustal domains has been considered to trigger doming and eventual extensional growth of intracratonic basins. 
It is interesting to note that the publications from the Atomic Minerals Directorate (Jeyagopal et al., 1996; 2011; Verma et al., 2011; Thomas et al., 2014) mention 'fertile basement granites and hydrothermal reactivation' as the primary source of Uranium Thorium mineralisation in the CB. It appears that the weathered Archean granitic rocks of the basement were thermally reactivated at a later date, enabling the emplacement of enriched mineralizing fluids into the sediments.

The late- to post-tectonic (1.28-1.3 Ga) Kanigiri granite and other satellite granitic stocks intruded NSB (see Fig. 3). They are interpreted to represent the last phase of the tectonic cycle of the collision between the Indian Peninsular and Antarctic block in this region. Magnesianfeldspathic arc magmatism has been established within the NFB (Sesha Sai, 2019). It has been interpreted to corroborate the subduction related magmatism witnessed along the continental margins of the Columbia supercontinent. Though Sesha Sai (2019) indicated an early Mesoproterozoic age for the VIN granites NSB (based on monazite dating), zircon $\mathrm{U}-\mathrm{Pb}$ dates will provide better constraints on the chronology of events.

Chalapathi Rao et al. (2016) had reported Mesoproterozoic lamproites ( $1.4 \mathrm{Ga})$ cutting through the Tadpatri Shale. They interpreted the involvement of multiple reservoirs for their genesis and linked its emplacement to extensional events related to Columbia breakup. Lamprophyric and related intrusions into the Cuddapah sediments are known from Chelima, Racherla, Giddalur and Zangamarajupalle along the NFB, as well as those in the surrounding basement of the EDC at Wajrakarur, Lattavaram, Mehboobnagar and Ramannapetta. It is evident that this region has seen a wide-spread event of lamprophyric intrusions around $1.4 \mathrm{Ga}$. Such magma has a unique deep-rooted and complex origin suggests significant mantle activity at this point in time. Lakshminarayana and Vijay Kumar (2018) suggested that some of the mafic intrusives occurring south of the Gani-Kalva fault may be of post-Kurnool age.

The PAkP in the NSB (Upadhyay et al., 2006; Subramanyam et al., 2015) is a complex array of intrusive bodies ranging in composition from nephelineand hornblende-syenites, quartz-monzonites, anorthosites, norites to gabbros. They are generally considered to represent products of melting of upper mantle sources and mixing with melts derived during island-arc related tectonism that were emplaced to upper crustal levels.

\section{Synthesis}

\section{Age of Sequences}

The interbedded volcanics from the Papaghni and Chitravati Groups provided the most reliable ages for their sedimentation. Sesha Sai (2017; Table 1) has compiled a comprehensive analysis of the available geochronological data. It is evident that the volcanics from these two groups were emplaced between 1.8 Ga and 1.9 Ga, with the work of Sheppard (2017a) reaffirming this. The ages of the mafic sills (that intrude the Vempalle and Tadpatri Formations are also consistent with this. Zachariah (1999) had given age of $1756 \pm 29 \mathrm{Ma}$ for uranium mineralization in the Vempalle Formation, while Rai (2015) had computed an age range of $1.9 \mathrm{Ga}-2.0 \mathrm{Ga}$ for dolomitization and uranium mineralization in the same formation.

The detrital zircons from the siliciclastic sediments from the $\mathrm{CB}$ yield $\mathrm{U}-\mathrm{Pb}$ ages ranging from $2.54 \mathrm{Ga}$ to $0.91 \mathrm{Ga}$ (Collins et al., 2015). They represent the ages of the provenance rocks but help constrain the maximum depositional age. Based on this, they suggested that the Papaghni and Chitravati Groups were fed by detritus from the Dharwar craton and may have been deposited after $2.0 \mathrm{Ga}$. These and other detrital zircon ages have been used by workers to infer the "maximum depositional age (MDA)' of the host sediments (e.g., Absar et al., 2016; Bhaskar Rao et al., 2016). It is necessary to recognize that this inference only ensures that the sediments are not 'older than the MDA' but does not provide any concrete evidence of the actual age of deposition. The zircons give ages of the rocks from the provenance and at a time also help identify the source-rocks very accurately. It does (in some cases) help in defining relative younger / older strata, based on the age populations. Uncertainties in the quotient of reworking and recycling (even for hydrothermally altered zircon crystals) that need to be resolved by the petrography of the host strata can also add to mistaken age attributes.

Sahoo et al. (2017) record age of $2.53 \mathrm{Ga}$ for magmatic zircons, while hydrothermally altered zircons 
provide Concordia of $2.32 \mathrm{Ga}$ and $2.12 \mathrm{Ga}$ from U$\mathrm{Pb}$ dating of zircons and $\mathrm{U}-\mathrm{Th}-\mathrm{Pb}_{\text {total }}$ dating of monazite and uraninite from both the basement and cover in the Palnad subbasin. They conclude that the host sediments (which have been mapped as Banganapalle Quartzite) may have been deposited between 2.53 and $2.12 \mathrm{Ga}$. This study discusses the problems of using detrital zircon ages for dating sediments and points out that if the ages are taken as depositional ages, these strata (which are currently classified in the Neoproterozoic Kurnool Group) may belong to much older (perhaps-Gulcheru Quartzites) formations. The unconformable relation between the Banganapalle Formation and the underlying Papaghni and Chitravati Groups is unambiguous in the KurnoolNandyal section, Yambayi-Ramallakota and Banganapalle sections. We, therefore, conclude that the zircons only provide a clue of the age of the provenance, not the sedimentation of the Kurnool Group.

Collins et al. (2015) and Sesha Sai et al. (2017) concluded the Nallamalai Group was deposited between $1.68 \mathrm{Ga}$ and $1.59 \mathrm{Ga}$, with inputs from the eastern tectonically active belt $(\mathrm{EGB}+\mathrm{NSB}$ or collectively the Krishna Orogen) as the primary source of detritus. The Srisailam Quartzite may have been deposited at the same time, further westwards in a separate basin, according to them. The Kurnool Group may be reaffirmed as distinctly Neoproterozoic in age, with zircons dated at $913 \pm 11$ Ma occurring in the Paniam Quartzite. To a large extent, this is consistent with the biotic remains reported from the Kurnool Group (Sharma et al., 2016; Sharma and Singh, 2019).

The geochronology of the NSB has been constrained by the ages of granites and ophiolites that are present in the belt (Saha et al., 2017; Sain et al., 2017; Saha and Sain, 2019). The Vinjamuru Group is thrusted over by the $1.9 \mathrm{Ga}$ Kandra ophiolite complex. This and the granulitic metamorphism $(1.6-1.7 \mathrm{Ga})$ in the Ongole domain together suggest that the deposition of the Vinjamuru sediments (in a deep marine environment on the oceanic floor) may have occurred before $1.9 \mathrm{Ga}$, while its metamorphism and tectonic upthrusting of the Vinjamuru Group may have occurred around $1.6 \mathrm{Ga}$. The Udaigiri domain represents a younger arc that evolved and was deformed around $1.3 \mathrm{Ga}$. The granitoid and alkaline intrusions testify to a younger age $(\sim 1.1 \mathrm{Ga})$ of the closure of the arc and the accretion of the NSB with the CB along the Vellikonda Thrust.

The Cuddapah Supergroup (excluding the Kurnool Group) was traditionally recognized as the oldest 'Purana' sequence (Kale and Phansalkar, 1991). Geochronological data has reaffirmed this to the extent that the Papaghni and Chitravati Groups are confirmed to be amongst the oldest of the Purana sediments, broadly coeval with the Bijawar and Gwalior Groups from the Vindhayan Basin (Basu and Bickford, 2015). It is possible to correlate them with the Bagalkot Group from the Kaladgi Basin (Joy et al., 2018), subject to alternate views on the age of the Kaladgi sediments (e.g.: Patil Pillai et al., 2018, 2019). On the basis of the new data on geochronology, sedimentation and deformation of the different crustal blocks, a schematic chronology of events is given in Fig. 7. The timing of the supercontinental assembly and break-up depicted in this figure are based on Cawood and Hawkesworth (2014) and Condie (2015).

\section{Tectonic Framework}

The age, content, and structural character of these sequences on the eastern margin of the Dharwar craton suggest that variable tectonic regimes were operational at different times during the Proterozoic. The earliest Proterozoic activity in this region is manifested as multiple pulses of mafic dyke swarms that intruded the EDC between $2.3 \mathrm{Ga}$ and $1.8 \mathrm{Ga}$. Most workers agree that magma generation related to the emplacement of these dykes is related to upper mantle melting. While some attribute this to a plume activity, others suggest that incipient rifting of the EDC may have led to the melt generation at depths. This period is one when the earliest supercontinental assembly (named Kenorland by Cawood and Hawkesworth, 2014) of Archean antiquity started to get reorganized, with break-up and reassembly of the constituent blocks into Columbia/Nuna supercontinent during the middle Paleoproterozoic (Pirajno and Santosh, 2015; Condie et al., 2015; Puetz et al., 2017). The Indian Peninsular shield has Antarctica-Australia on its eastern side in this assembly (Piper, 2018).

The thermal events and rifting of the EDC along its eastern margin led to the generation of the Papaghni subbasin as a rifted passive-margin system around $1.9 \mathrm{Ga}$. Sediments derived by weathering of the 


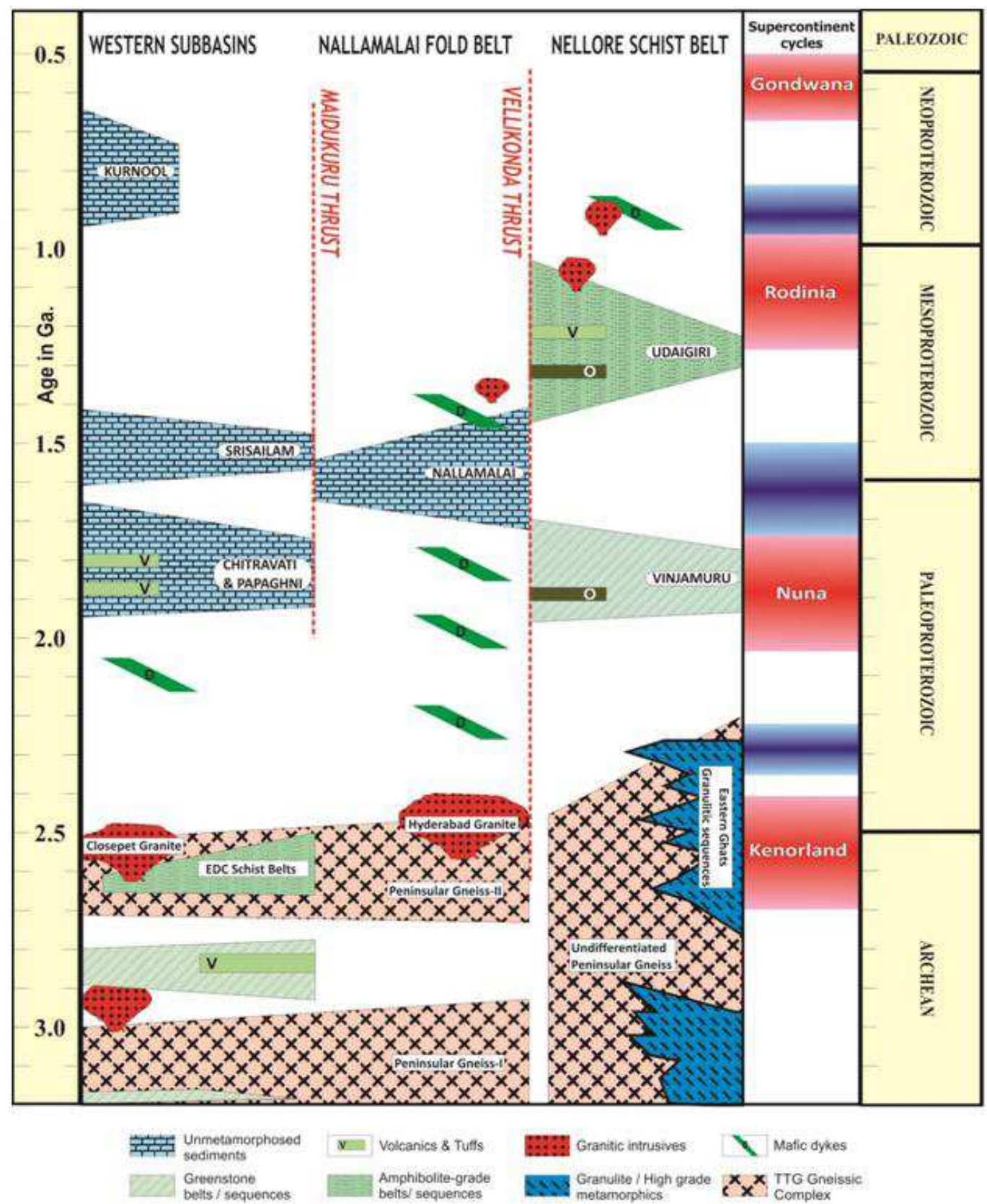

Fig. 7: Compilation of available ages of various units in the Cuddapah Basin and Nellore Schist Belt and adjoining region (updated from Kale, 2016), based on geochronological data discussed in the text. The terrain bounding thrusts are only used notionally to separate the crustal blocks. The geochronological boundaries are as defined by ICS (2017). Although depicted as different components, all crystalline rocks of Archean (and partly very early Paleoproterozoic age) occur as the basement for the Proterozoic sedimentary successions from this region; and have also served as the provenance for the sediments in the western subbasins. The boundaries of the Proterozoic sequences are shown as time-transgressive to indicate the range of uncertainties in their ages. The supercontinental cycles based on global data compilations by Cawood and Hawkesworth (2014) and Condie et al. (2015) indicate peak assembly of Proterozoic supercontinents (in red) and periods of break-up (blue)

emergent cratonic block fed this epicratonic basin. It may have continued to deepen and receive sediments till around $1.7 \mathrm{Ga}$. As suggested by Basu and Bickford (2015), the contemporary eastern sea-board of
Peninsular India has hosted several disconnected basins along with it. Further eastward, this continent margin had an oceanic interface, preserved in the form of the Vinjamuru Group in the NSB. The presence of 
silicic tuffs interbedded within the Chitravati Group suggests that there would have been an active (? arctype) volcanic activity in the vicinity. This establishes that a passive continental margin must be present during the period of $1.9 \mathrm{Ga}$ to almost $1.6 \mathrm{Ga}$ on the east of the Dharwar craton.

The global cycle of amalgamation of the Nuna (Columbia) supercontinent is reflected in the cessation of sediments in the Papaghni subbasin of the CB and the tectonism of the Vinjamuru block in the NSB. Closure of oceanic realms and compressive tectonism may have led to the emergence of a fore-arc sector in the NSB and a retro-arc continental basin along the Nallamalai belt (including perhaps the Srisailam subbasin). The tight folding along the NFB and overthruting recorded along the Maidukuru Thrust are consistent with this model. The eventual closure of the eastern arc (Udaygiri block from the NSB) and its collisional accretion with the $\mathrm{CB}$ along the Vellikonda Thrust appears to match well with the late Mesoproterozoic global cycle that led to the evolution of Rodinia supercontinental assembly. These accretionary tectonics produced melts that were emplaced as the granitoids and alkaline rocks in the NSB and some parts of the CB. This was followed by a period of tectonic quiescence which ended with the extensional sagging in parts of the $\mathrm{CB}$, yielding the Kurnool Group of sediments.

If the $\mathrm{CB}$ (on a stand-alone basis) is appraised from a sedimentary basin perspective (Allen and Allen, 2005; Allen et al., 2015), its basement of EDC and position on the cratonic edge places it as a continental margin basin. However, its subbasins display diverse growth histories at differing times, and therefore it must be recognized as a polyhistory basin (Kale, 1991). The Papaghni subbasin is a rifted continental margin basin, given the mafic lavas interbedded within it and the boundary faults that were active during its growth. The Srisailam and Kurnool subbasins may be categorized as cratonic sag basins (sensu: Table 2.3: Allen et al., 2015). Pending more data, it is difficult to categorize the nature of the Nallamalai sedimentation in this framework. Unquestionably it is an allochthonous crustal block that has been thrust over the western subbasins. How it relates to the collisional domain in the NSB-Ongole sectors remains an open question.
The model of the evolution of this collage of crustal blocks located on the eastern margin of the EDC, abutting against each other with tectonic contacts enumerated above, may be taken as one of the possible emerging hypotheses. We however recognise that much more work and details are required to develop robust model of the Proterozoic tectonic evolution of the $\mathrm{CB}$ and its adjoining crustal blocks.

\section{Concluding Remarks}

We have attempted here to compile the available knowledge on the Cuddapah basin and adjoining crustal blocks and put it in a framework of a working hypothesis. While doing so, the more recent publications have been cited and focussed on. We acknowledge that there has been a lot of work by others that may not be cited here but is covered in the cited works.

Several areas of study require immediate attention for a more robust database on the $\mathrm{CB}$ and its surrounding region that hosts events of Proterozoic rifting, passive margin evolution, collisional tectonics, and supracrustal deformation. It cannot be overemphasized that more controlled geochronology, paleomagnetic data with greater distribution and resolution is required. Along with that, we recommend the following for further critical study.

\section{Sedimentological Aspects}

Available data and the studies spanning more than a century have established the broad contours of the sedimentary architecture, facies, and primary structuresin the CB. This needs to be supplemented by characterization of the provenance, sea-water chemistry and depositional environments using sophisticated modern tools of isotopic and chemical analyses. While such information is available along select traverses and around mineral deposits of economic importance, a basin-wide database is desirable. Similar petrogenetic studies to qualify the original sedimentology of the metamorphosed sequences in the NSB and NFB have started but details are awaited. They will also ensure that more robust correlations of strata across the region can be made. Once this is available, detailed sequence stratigraphic analysis will enable deciphering of the relative sea-level curves across different segments 
of the basin, with far better precision than the modeled curves (Fig. 6). Given the spectrum of depositional environments and varied tectonic settings in this region, such studies could contribute significantly to the global Proterozoic database.

\section{Structural Analyses}

The work of GSI and academia in different parts of the $\mathrm{CB}$ enumerated above has helped decipher the structural patterns in a more detailed manner than before. However, additional focus is needed for a structural map across the NFB and its bounding thrusts. This could resolve some of the ambiguous correlations of strata (e.g., Gandikota \& Nagri Quartzites, superposition of strata within the Nallamalai Group and its relation with the Srisailam Formation) that still exist. Similar structural studies in the NSB are already demonstrating their efficacy in resolving mutual relationships between rocks with diverse metamorphic grades and enabling a better modeling of the structural framework. This needs to be taken to the next level in the days to come.

\section{Igneous Petrogenesis}

This is an area that has lesser ambiguities. However, models of the mafic igneous rocks in this region vacillate between rift-generated or plume generated models. Perhaps both operated at different times. Better geochronological controls are desirable for the same, besides the petrochemical characterization.

\section{Geophysical Data}

Exhaustive aeromagnetic, gravity, and seismic data are available across this region, with the organisations

\section{References}

Allen P A and Allen J R (2005) Basin Analysis: Principles and Applications $2^{\text {nd }}$ Edition, Wiley-Blackwell, $560 \mathrm{p}$

Allen P A, Eriksson P G, Alkmim F F, Betts PG, Catuneanu O, Mazumdar R, Meng Q and Yong GM (2015) Precambrian basins of India: stratigraphic and tectonic context. In: Precambrian Basins of India: stratigraphic and tectonic perspective (Eds: Mazumdar R and Eriksson PG) Geological Society London Memoirs 43 5-28

Anand M, Gibson S A, Subba Rao K V, Kelley S P and Dickin A P (2003) Early Proterozoic melt generation processes like the GSI, AMD and NGRI. Geophysical analysis has either been on a regional (crustal-scale) basis or for economic mineral prospecting. A high-resolution seismic profiling across this collage of terranes could help resolve the structural and sequence stratigraphic issues. Perhaps the exploration agencies could take a lead role in this. A compilation of this data and its comparison with the available geological crosssections and strata continuity has the capacity to create shallow-crustal cross-sections and generate robust tectonic models.

This region comprises of (four) extensional subbasins hosting sediments, a fold belt (NFB) and a mobile (collisional) belt (NSB) successively from west to east. How the constituent crustal blocks in this collage of terranes are linked to each other in terms of tectonic events and crustal growth remains to be deciphered satisfactorily. The agenda is large, multidisciplinary and multifaceted. It is hoped that this compilation helps future workers in focussing their efforts improving the knowledge of this mineral-rich Proterozoic basin and its adjoining terrains than is available today.

\section{Acknowledgments}

We thank Prof. D M Banerjee for inviting this review. DS and SPD are thankful to Indian Statistical Institute for the infrastructural facilities and funding for research on the Proterozoic basins. VSK and SPP thank DST for funding research in the Purana basins from time to time. VVSS and VT thank the Director-General, Geological Survey of India. We thank the anonymous referee for constructive suggestions.

beneath the intra-cratonic Cuddapah Basin, Southern India Journal of Petrology 44 2139-2171

Basu A and Bickford M E (2015) An alternate perspective on the opening and closing of the intracratonicPurana Basins in Peninsular India Journal of the Geological Society of India 85 5-25

Basu H, Dandele P S, Kumar K R, Achara, K K and Umamaheswara K (2017) Geochemistry of black shales from the Mesoproterozoic Srisailam Formation, Cuddapah basin, India: Implications for provenance, palaeoweathering, tectonics, and timing of Columbia breakup Chemie 
der Erde http://dxdoiorg/101016/jchemer201710002

Basu H, Satynarayana Sastry R, Achar K K, Umamaheswara K and Parihar P S (2014) Paleoproterozoic fluvio-aeolian deposits from the lower Gulcheru Formation, Cuddapah Basin, India Precambrian Research 246 321-333

Bhattacharjee P, Goswami S, Bhagat S and Verma M B (2018) Gypsum-anhydrites in 19 Ga Vempalle Formation, Cuddapah basin, India: A note on the Palaeoproterozoic environment and diagenetic condition Journal of Earth System Science 127 114-126

Bhaskar Rao Y J, Khadke N and Vijaya Kumar T (2016) Research highlights on the evolution of Precambrian crust of Peninsular India: constraints from recent zircon $\mathrm{U}-\mathrm{Pb}$ geochronology results Proceedings Indian National Science Academy 82 489-503

Bose S, Chakrabarti G and Shome D (2017) Evolution of PalaeoMesoproterozoic open coast ramp-clues from stromatolitebearing carbonate facies of Vempalle Formation, Cuddapah Basin, India Arab Journal of Geosciences doi:101007/ s12517-017-2988-y

Cawood P A and Hawkesworth C J (2014) Earth's middle age Geology 42 503-506

Chakrabarti G, Shome D, Kumar S, Stephens III G M and Kah L C (2016) Carbonate platform development in a Paleoproterozoic extensional basin, Vempalle Formation, Cuddapah Basin, India Journal of Asian Earth Sciences 91 263-279

Chakraborty K, Mukhopadhyay P K and Pankaj P (2016) Magmatism in Western Cuddapahs: The Mafic Sills and Lava Flows of Vempalle and Tadpatri Formations Journal of the Geological Society of India 87 631-660

Chalapathi Rao N V, Atiullah Kumar A, Sahoo S, Nanda P, Chahong N, Lehmann B and Rao K V S (2016) Petrogenesis of Mesoproterozoic lamproite dykes from the Garledinne (Banganapalle) cluster, south-western Cuddapah Basin, southern India Mineralogy and Petrology 110 247-268

Chandrakala K, Mall D M, Sarkar D and Pandey O P (2013) Seismic imaging of the Proterozoic Cuddapah basin, South India and regional geodynamics Precambrian Research 213 p 277-289

Chandrakala K, Pandey O P, Prasad A S S S R S and Sain K (2015) Seismic imaging across the Eastern Ghats Belt - Cuddapah basin collisional zone, southern Indian Shield and possible geodynamic implications Precambrian Research 271 5664

Chatterjee C, Ravikant V and Kaptan O P (2016) Paleoproterozoic Cordilleran-style accretion along the southeastern margin of the eastern Dharwar craton: Evidence from the Vinjamuru arc terrane of the Krishna orogen, India Lithos 263 122142

Chatterjee N and Bhattacharji S (2001) Petrology, geochemistry and tectonic setting of the mafic dykes and sills associated the evolution of the Proterozoic Cuddapah basin, South India ProceedingsIndian Academy of Sciences (Earth Planet Science) 110 433-453

Chetty T R K (2001) The Eastern Ghats Mobile Belt, India: A Collage of Juxtaposed Terranes (?) Gondwana Research 4 319-328 doi: 10.1016/S1342-937X(05)70332-4

Chetty T R K (2011) Tectonics of Proterozoic Cuddapah basin, southern India: a conceptual model Journal of the Geological Society of India 78 446-456

Chetty T R K and Santosh M (2013) Proterozoic orogens in southern Peninsular India: contiguities and complexities Journal of Asian Earth Sciences 15 p, doi: 101016/ jjseaes201302021

Collins A S, Patranabis-Deb S, Alexander E, Bertram C N, Falster G M, Gore R J, Mackintosh J, Dhang P C, Saha D, Payne J L, Jourdan F, Backe G, Halverson G P and Wade B P (2015) Detrital mineral age, radiogenic isotopic stratigraphy and tectonic significance of the Cuddapah Basin, India Gondwana Research 28 1294-1309

Condie K C, Arndt N, Davalle A and Puetz S J (2017) Zircon age peaks: production or preservation of continental crust? Geosphere 13 9p doi: 10.1130/GESO13611

Condie K C, Pesarevsky S A, Korengaga J and Gardoll S (2015) Is the rate of supercontinent assembly changing with time? Precambrian Research 259 278-289

Das S, Shukla D and Mitra S K (2016) Evidences of inclined transpression at the contact between Vinjamuru group and Udayagiri group of Nellore Schist Belt, Andhra Pradesh, India Journal of Earth System Science 125 1007-1020

Das S and Chakraborty M (2017) Splised Thematic Mapping of ultrapotassic volcanic rocks and associated magmatism in the Nallamalai Fold Belt of Proterozoic Cuddapah basin and their bearing on the mineralisation around Rajampata area, Cuddapah district, Andhra Pradesh Records of the Geological Survey of India 149 22-25

Dasgupta S, Bose S, Bhowmik S K and Sengupta P (2017) The Eastern Ghats Belt, India, in the context of supercontinent assembly In: Crustal Evolution of India and Antarctica: The Supercontinent Connection (Eds: Pant NC and Dasgupta S) Geological Society of London Special Publication 457 87-104

French J E, Heaman L M, Chacko T and Srivastava R K (2008) 
1891-1883 Ma southern Bastar-Cuddapah mafic igneous events, India: a newly recognized large igneous province Precambrian Research 160 308-322

Ganguli S S, Singh S, Das N, Maurya D, Pal S K and Rama Rao J V (2019) Gravity and magnetic survey in the southwestern part of Cuddapah Basin, India and its implications for shallow crustal architecture and mineralization Journal of the Geological Society of India 93 419-430

Geological Survey of India (1981) Explanatory brochure on Geology and Mineral Map of Cuddapah Basin 1-21

Goswami S, Bhattacharjee P, Bhagat S, Suresh Kumar and Zakaulla S (2015) Petrography of chert nodules in stromatolitic dolostone of Vempalle Formation, along Tummalapalle Motnutalapalle, Cuddapah Basin, India Indian Journal of Geosciences 69 13-24

Goswami S, Mukherjee A, Zakaulla S and Rai A K (2016) Stress states, faulting and their effects on the Papaghni Group, Cuddapah Basin, India: a study along Giddankivaripalle Madyalabodu tract Indian Journal of Geosciences 70 116

Goswami S, Mukherjee A, Bhattacharjee P and Zakaulla S (2017a) Primary sedimentary structures and MISS in Gulcheru quartzite along SW part of Cuddapah Basin Journal of the Geological Society of India 89 511-520

Goswami S, Bhagat S, Zakaulla S, Kumar S and Rai A K (2017b) Role of Organic Matter in Uranium Mineralisation in Vempalle Dolostone; Cuddapah Basin, India Journal of the Geological Society of India 89 145-154

Goswami S, Upadhyay P K, Bhagat S, Zakaulla S, Bhatt A K, Natarajan V and Dey S (2018) An approach of understanding acid volcanics and tuffaceous volcaniclastics from ûeld studies: A case from Tadpatri Formation, Proterozoic Cuddapah basin, Andhra Pradesh, India Journal of Earth System Science 127 1-20 doi: 101007/ s12040-018-0929-0

International Commission on Stratigraphy (2017) The ICS International chronostratigraphic chart http:// wwwstratigraphyorg/ICSchart/chronostrat Chart 2017-02

Jeyagopal A V, Kumar P and Sinha R M (1996) Uranium mineralisation in the Palnad sub-basin, Cuddapah basin, Andhra Pradesh, India Current Science 71 957-959

Jeyagopal A V, Deshpande M S, Gupta S, Ramesh Babu P V, Umamaheshwar K and Maithiani P B (2011) Uranium mineralisation and association of carbonaceous matter in Koppanuru area, Palnad sub-basin, Cuddapah basin, Andhra Pradesh Indian Mineralogist 45 100- 111
Jeyagopal A V, Rai A K and Parihar P S (2012) Tectonic setting of Tummalapalle uranium deposit in the southern margin of Cuddapah basin, Andhra Pradesh Exploration and Research Atomic Minerals 22 43-54

Jokhan Ram (2012) Neoproterozoic successions in Peninsular India and their hydrocarbon prospectivity Geological Society of London Special Publication 366 59-73

Joy S, Patranabis-Deb S, Saha D, Jelsma H, Maas R, Söderlund U, Tappe S, van der Linde G, Banerjee A and Krishnan U (2018) Depositional history and provenance of cratonic "Purana" basins in southern India: A multipronged geochronology approach to the Proterozoic Kaladgi and Bhima basins. Geological Journal 28 p. doi:10.1002/gj.3415

Kaila K L and Tewari H C (1985) Structural trends in the Cuddapah basin from Deep Seismic Soundings (DSS) and their tectonic implications Tectonophysics 115 69-86

Kaila K L, Tewari H C, Roy Chowdhury K, Rao V K, Sridhar A R and Mall D M (1987) Crustal structure of the northern part of the Proterozoic Cuddapah basin of India from deep seismic soundings and gravity data Tectonophysics $1401-12$

Kale V S (1991) Constraints on the evolution of the Purana basins of Peninsular India Journal of the Geological Society of India 38 231-252

Kale V S (2016) Proterozoic Basins of Peninsular India: Status within the Global Proterozoic Systems Proceedings Indian National Science Academy 82 461-477

Kale V S and Phansalkar V G (1991) Purana Basins of Peninsular India: A review Basin Research 3 1-31

Khan T, Srinivasa Sarma D, Somasekhar V, Ramanaiah S and Ramakrishna Reddy N (2019) Geochemistry of the Palaeoproterozoic quartzites of Lower Cuddapah Supergroup, South India: implication for the palaeoweathering, provenance, and crustal evolution. Geological Journal 25 p doi. 10.1002/gj.3849.

Khelen A C, Manikyamba C, Ganguly S, Singh Th D, Subramanyam K S V, Ahmad S M and Reddy M R (2017) Geochemical and stable isotope signatures of Proterozoic stromatolitic carbonates from the Vempalle and Tadpatri Formations, Cuddapah Supergroup, India: Implications on palaeoenvironment and depositional conditions Precambrian Research 298 365-384

King W (1872) On the Kadapah and Karnûl Formations in the Madras Presidency Memoir Geological Survey of India $\mathbf{8}$ $1-293$

Kishore R K and Ram Rao Ch (2004) Basement characteristics of the Papaghni basin of Eastern Dharwar craton (India) - An 
inference from aeromagnetic study Journal of Indian Geophysical Union 4 311-317

Krishna Brahmam N (1989) Gravity and seismicity of the Cuddapah basin and surrounding places Journal of the Geological Society of India 34 373-384

Krishna Brahmam N, Sarma J R, Aravamadhu P S and Subbarao D V (1986) Explanatory brochure on Bouger gravity anomaly map (NGRI/GPH-6) of Cuddapah basin, India with scale 1:250,000 NGRI, Hyderabad $36 \mathrm{p}$

Kumar A, Hamilton M A and Halls H C (2012) A Paleoproterozoic giantradiating dyke swarm in the Dharwarcraton, southern India Geochemistry Geophysics Geosystems 13 1-12

Kumar A, Parasharumulu V and Nagaraju E (2015) A 2082 Ma radiating dyke swarm in the Eastern Dharwar craton, southern India and its implications to Cuddapah basin formation Precambrian Research 266 490-505

Lakshminarayana G and Vijay Kumar D (2018) Occurrence of High Level magma intrusives and Associated Mineralization near Gani Inlier, Kurnool Sub-Basin, Cuddapah Basin, India Journal of the Geological Society of India 91 431440

Lakshminarayana G, Vijay Kumar D, Kalayan Kumar S and Raghavendra G (2019) Extension related magmatism and basin evolution in northwestern part of the Cuddapah rift, India. Journal of the Geological Society of India 94 149161

Leelanandam C (1989) The Prakasam Alkaline Province in Andhra Pradesh, India Journal of the Geological Society of India 34 25-45

Matin A (2015) Tectonics of the Cuddapah Basin and a model of its evolution: a review. In: Precambrian Basins of India: Stratigraphic and Tectonic Context (Eds: Mazumder R and Eriksson P G) Geological Society London Memoirs 43 231-254

Matin A and Guha J (1996) Structural geometry of the rocks of the southern parts of the Nallamalai Fold Belt, Cuddapah Basin, Andhra Pradesh Journal of the Geological Society of India 47 535-545

Majumder T and Patranabis-Deb S and Nemec W (2015) Palaeoproterozoic sedimentation in the Cuddapah Basin of south-eastern India31 st IAS Meeting of Sedimentology, 22-25th June 2015, Kraków, Poland

Meert J G, Pandit M K, Pivarunas A, Katusin K and Sinha A K (2017) India and Antarctica in the Precambrian: A brief analysis In: Pant NC and Dasgupta S (Eds.) Crustal Evolution of India and Antarctica: The Supercontinent Connection Geological Society London Special Publication
457 339-351

Meijerink A M J, Rao D P and Rupke J (1984) Stratigraphic and structural development of the Precambrian Cuddapah Basin, SE India Precambrian Research 26 57-104

Merdith A S, Collins A S, Williams S E, Pisarevsky S, Foden J D, Archibald D, Blades M L, Alessio B, Armistead S, Plavsa D, Clark C and Dietmar Muller R (2017) A full-plate global reconstruction of the Neoproterozoic Gondwana Research 50 84-134

Misra D C and Ravi Kumar M (2013) Proterozoic orogenic belts and rifting of Indian cratons: geophysical constraints Geoscience Frontiers 5 25-41

Mitra R, Chakrabarti G and Shome D (2018a) Development of Stromatolites in a mixed siliciclasticcarbonate succession: An example from Palaeo-Mesoproterozoic Tadpatri Formation, Cuddapah Basin, India International Journal of Research and Analytical Reviews 5 380-384

Mitra R, Chakrabarti G and Shome D (2018b) Geochemistry of the Palaeo-Mesoproterozoic Tadpatri SHALES, Cuddapah Basin, India: implications on provenance, paleoweathering and paleoredox conditions Acta Geochimica 37 715-733

Mukherjee S, Goswami S and Mukherjee A (2018) Structures and Their Tectonic Implications of the Southern Part of Cuddapah Basin, Andhra Pradesh, India Iranian Journal of Science and Technology Transactions A: Science $\mathbf{4 3} 1$ 17 doi: 10.1007/s40995-018-0566-0

Nagaraja Rao B K, Ramalingaswamy G, Rajurkar S T and Ravindra Babu B (1987) Stratigraphy, structure and evolution of the Cuddapah basin In: Purana basins of Peninsular India (Middle to Late Proterozoic) Geological Society of India Memoirs 6 33-86

Nagaraju E, Parashuramulu V, Kumar A and Srinivas Sarma D (2018) Paleomagnetism and geochronological studies on a $450 \mathrm{~km}$ long $2216 \mathrm{Ma}$ dyke from the Dharwar craton, southern India Physics of the Earth and Planetary Interiors $274222-231$

Narayanswami S (1966) Tectonics of Cuddapah basin Journal of the Geological Society of India $733-50$

Pandey A and Chalapathi Rao N V (2019) Coupled assimilation and fractional crystallization (AFC) and mantle plume source(s) contribution in the generation of Paleoproterozoic mafic dykes of the Eastern Dharwar Craton, Southern India Journal of the Geological Society of India 93 157-162

Pandey A, Chalapathi Rao N V, Pandit D, Pankaj P, Pandey R, Sahoo S and Kumar A(2017) Subduction - tectonics in the 
evolution of the eastern Dharwar craton, southern India: insights from the post-collisional calc-alkaline lamprophyres at the western margin of the Cuddapah basin Precambrian Research 298 235-251

Panja M, Chakrabarti G and Shome D (2019) Earthquake-induced soft-sediment deformation structures in the Paleoproterozoic Vempalle Formation (Cuddapah basin, India) Carbonates and Evaporites 34 491-505

Patranabis-Deb S, Saha D and Tripathy V (2012) Basin stratigraphy, sea-level fluctuations and their global tectonic connections - evidence from the Proterozoic Cuddapah Basin Geological Journal 47 263-283 doi: 10.1002/gj1347)

Patranabis-Deb S and Santosh M (2016) Paleoproterozoic extension of the east Dharwar craton and its imprint on the Papaghni sub-basin, India $35^{\text {th }}$ IGC Abstract Volume no 1552, Cape Town SA

Patranabis-Deb S, S30wakiewicz M, Tucker M E, Pancost R D and Bhattacharya P (2016) Carbonates and related facies with vestiges of biomarkers from the Chattisgarh Basin, India: Clues to redox conditions in the Mesoproterozoic ocean Gondwana Research 35 411-424

Patranabis-Deb S, Majumder T and Khan S (2018) Lifestyles of the Palaeoproterozoic stromatolite builders in the Vempalle Sea, Cuddapah Basin, India Journal of Asian Earth Sciences $157360-370$

Patil Pillai S, Pande K and Kale V S (2018) Implications of new 40Ar/39Ar age of Mallapur Intrusives on the chronology and evolution of the Kaladgi Basin, Dharwar craton, India Journal of Earth System Science 127 1-32

Patil Pillai S, George B G, Ray J S and Kale V S (2019) Comments on the article: Depositional history and provenance of cratonic Purana basins in southern India: a multipronged geochronology approach to the Proterozoic Kaladgi and Bhima basin by Joy et al. 2018 Geological Journal doi:10.1002/gj.3589

Patil Pillai S and Kale V S (2019) Interplay Between Tectonics \&Eustacy in a Proterozoic Epicratonic, Polyhistory Basin, North Dharwar Craton In Tectonics and Structural Geology: Indian Context (Ed: Mukherjee S) 75-114 Springer Geology doi: 101007/978-3-319-99341-6_4

Phansalkar V G, Kale A S, Karmalkar N R and Kale V S (1991) An unusual evaporate association from the Papaghni Group, Cuddapah Basin Journal of the Geological Society of India 37 75-79

Piper J D A (2018) Dominant Lid tectonics behavior of continental lithosphere in Precambrian times: paleomagnetism confirms prolonged quasi-intergrity and absence of supercontinental cycles Geoscience Frontiers 9 61-89

Puetz S J, Condie K C, Pisarevsky S, Davaille A, Schwarz C J and Ganade C E (2017) Quantifying the evolution of the continental and oceanic crust Earth Science Reviews 164 $63-83$

Radhakrishna B P (1987) Editorial: Purana Basins of India (Middle to Late Proterozoic) Geological Society of India Memoir 6 $\mathrm{i}-\mathrm{xv}$

Rai A K, Pandey U K, Zakaulla S and Parihar P S (2015) New 1.9-2.0 Ga, $\mathrm{Pb}-\mathrm{Pb}$ (PbSL), age of dolomites from Vempalle Formation, Lower Cuddapah Supergroup, Eastern Dharwar craton, India Journal of the Geological Society of India $\mathbf{8 6}$ $131-136$

Rajurkar S T and Ramalingaswami G (1975) Facies variations within the Upper Cuddapah Strata in the northern part of the Cuddapah Basin. In: Precambrian Geology of the Peninsular Shield, Part 1 Geological Survey of India Misccellaneous Publications 23 157-164

Ram Babu H V (1993) Basement structure of Cuddapah basin from gravity anomalies Tectonophysics 223 411-422

Ramam P K and Murty V N (1997) Geology of Andhra Pradesh Geological Society of India Bangalore 244

Ramakrishnan M and Vaidyanadhan R (2008) Geology of India, Vol 1, Geological Society of India Bangalore 556

Ravikant V (2010) Paleoproterozoic ( 1.9 Ga) extension and breakup along the eastern margin of the Eastern Dharwar Craton, SE India: New $\mathrm{Sm}-\mathrm{Nd}$ isochron age constraints from anorogenic mafic magmatism in the Neoarchean Nellore greenstone belt Journal of Asian Earth Sciences 37 67-81

Roy A B and Purohit R (2018) Indian Shield, Precambrian evolution and Phanerozoic Reconstitution Elsevier Amsterdam, Netherlands 387

Saha D (2002) Multi-stage deformation in the Nallamalai Fold Belt, Cuddapah Basin, South India - implications for Mesoproterozoic tectonism along Southeastern margin of India Gondwana Research 5 701-719

Saha D (2004) Structural asymmetry and Plate tectonic set-up for a Proterozoic fold and thrust belt: Nallamalai fold belt and adjoining terrane, South India Geological Survey of India Special Publication 84 101-119

Saha D, Bhowmik S K, Bose S and Sajeev K (2016) Proterozoic tectonics and trans-Indian mobile belts: A status report Proceedings Indian Academy of Sciences (Earth Planet Science) 82 445-460

Saha D, Patranabis-Deb S and Collins A S (2016) Proterozoic 
Stratigraphy of Southern Indian Cratons and Global Context Stratigraphy\& Timescales 1 1-59 doi: 101016/ bs sats 2016 10003

Saha D, Mazumder R and Kar R (2017) Shallow marine to pelagic sediments from a dismembered ophiolite, Kandra, southern India - Glimpses of ancient subduction zone related sedimentation Gondwana Research 49 21-41

Saha D and Sain A(2019) Multiple convergences along an Archean craton margin: clues from Proterozoic ophiolite remnants, granites and granulite domains along the SE margin of India Journal of Geodynamics 129 44-58

Saha D and Tripathy V (2012) Palaeoproterozoic sedimentation in the Cuddapah Basin south India and regional tectonicsa review In: Paleoproterozoic of India (Eds: Mazumder R and Saha D) Geological Society of London Special Publication 365 159-182

Sahoo D, Pruseth K L, Upadhyay D, Ranjan S, Pal D C, Banerjee R and Gupta S (2017) New constraints from zircon, monazite, and uraninite dating on the commencement of sedimentation in the Cuddapah basin,India Geological Magazine 147 1230-1246

Sain A, Saha D, Joy S, Jelsma H and Armstrong R (2017) New SHRIMP age and microstructures from a deformed Atype granite, Kanigiri, southern India: constraining the hiatus between orogenic closure and post-orogenic rifting Journal of Geology 125 241-259

Scotese C (2017) Atlas of Ancient Oceans \& Continents: 1.5 billion years - Today Paleomap Project Report: www.scotese.com

Sesha Sai V V (2009) Sheeted dykes in Kandra ophiolite complex, Nellore schist belt, Andhra Pradesh — vestiges of oceanic crust Journal of the Geological Society of India 74 509514

Sesha Sai V V (2013) Proterozoic granite magmatism along the terrane boundary tectonic zone to the East of Cuddapah Basin, Andhra Pradesh - petrotectonic implications for Precambrian crustal growth in Nellore Schist Belt of Eastern Dharwar Craton Journal of the Geological Society of India 81 167-182

Sesha Sai V V (2019) Proterozoic magnesian feldspathic magmatism in the Nallamalai fold belt, Southern India petrogenesis of Vellaturu - Ipuru - Nakerikally (VIN) arc magmatic granites, Eastern Dharwar craton Journal of the Geological Society of India 93 409-418

Sesha Sai V V, Reddy N R K, Reddy U V B, Khanna T C, Tripathy V and Ramakrishna P (2016) Field and petrological studies of the sedimentary sequence and associated mafic-felsic magmatic rocks in the Mallela section, Chitravati Group, SW partof Proterozoic Cuddapah basin, Eastern DharwarCraton, SE, India Extended abstract: National Seminar on Multidisciplinary studies on the Cuddapah basin, Andhra Pradesh and Telangana, India (NMDSCB) 2016 107-109.

Sesha Sai V V, Tripathy V, Bhattacharjee S and Khanna T C (2017) Paleoproterozoic magmatism in the Cuddapah basin, India Journal of Indian Geophysical Union 21 516525

Sergeev V N, Sharma M and Shukla Y (2012) Proterozoic fossil cyanobacteria Palaeobotanist 61 189-358

Sheppard S, Rasmussen B, Zi J W, Sekhar S, Sarma S, Ram Mohan M, Krape• B, Wilde S A and McNaughton N J (2017) Sedimentation and magmatism in the Paleoproterozoic Cuddapah Basin, India: Consequences of lithospheric extension Gondwana Research 48 153163

Sharma M, Tiwari M, Ahmad S, Shukla R, Shukla B, Singh V K, Pandey S K, Ansari A H, Shukla Y and Kumar S (2016) Palaeobiology of Indian Proterozoic and early Cambrian successions-Recent developments Proceedings Indian Academy of Sciences 82 559-579

Sharma M and Shukla Y (2012a) Occurrence of helically coiled microfossil Obruchevellain the Owk Shale of the Kurnool Group and its significance Journal of Earth System Science $121755-768$

Sharma M and Singh V K (2019) Megascopic carbonaceous remains from Proterozoic basins of India In: Geological Evolution of the Precambrian Indian Shield (Ed: Mondal MEA) Society of Earth Scientists 725-749 doi: 101007/ 978-3-319-89698-4_27

Sheppard S, Rasmussen B, Zi J W, Soma Sekhar V, Sarma D S, Ram Mohan M and McNaughton N J (2017a) Sedimentation and magmatism in the Paleoproterozoic Cuddapah Basin, India: Consequences of lithospheric extension Gondwana Research 48 153-163

Sheppard S, Rasmussen B, Zi, J W Soma Sekhar V, Srinivasa Sarma D, Ram Mohan M and Krapez B (2017 b) U-Pb dating of metamorphic monazite establishes a Pan-African age for tectonism in the Nallamalai Fold Belt, India Journal Geological Society London 174 1062-1069

Singh D, Manikyamba C, Subramanyam K S V, Ganguly S, Khelen A C and Reddy R (2018) Mantle heterogeneity, plumelithosphere interaction at rift controlled ocean-continent transition zone: Evidence from trace-PGE geochemistry of Vempalle flows, Cuddapah Basin, India Geoscience 
Frontiers 9 1809-1827

Sivasubramaniam R, Birua M K, Kumar S, Christopher Arulmani P, Zakaulla S and Rai A K (2016) Petro-physical characteristic of uraniferous dolostone in Vempalle Formation, Tumallapalle Uranium Deposit, Andhra Pradesh, India Exploration and Research for Atomic Minerals 26 137-142

Somasekhar V, Ramanaiah S and Srinivasa Sarma D (2018) Geochemical characterization of the siliciclastic rocks of Chitravati Group, Cuddapah Supergroup: implications for provenance and depositional environments Journal of Earth System Sciences 127 doi 10.1007/s12040-018-0955-y

Srikantia S V (1984) Kuppalapalle volcanic - a distinct Upper Papaghni volcanic activity in the Cuddapah Basin Journal of the Geological Society of India 25 775-779

Srinivasan K N and Roop Kumar D (1995) Geological mapping of Nellore schist belt, Prakasam district, AP Unpublished Progress Report of the Geological Survey of India FS 1992-93

Subramanyam K S V, Reddy U V B, Balaram V and Roy P (2015) Petrography and geochemistry (Trace, REE, PGE) of PeddaCherlopalle Gabbro - Diorite Pluton, Prakasm igneous province, Andhra Pradesh, India Open Geosciences 7 264-288

Subramanyam K S V, Santosh M, Yang Q-Y, Zhang Z-m, Balaram V and Reddy U V B (2016) Mesoproterozoic island arc magmatism along the south-eastern margin of the Indian Plate: Evidence from geochemistry and zircon $\mathrm{U}-\mathrm{Pb}$ ages of mafic plutonic complexes Journal of Asian Earth Sciences $130116-138$

Tewari H C and Rao V K (1987) A high-velocity intrusive body in the upper crust in the southwestern part of Cuddapah basin as delineated by Deep Seismic Sounding and gravity modeling In Purana Basins of Peninsular India (Ed: Radhakrishna BP) Geological Society of India Memoir 6 349-356

Tripathy V and Saha D (2010) Structure and low-grade metamorphism of the east-central part of the Proterozoic Nallamalai fold belt, south India - thrust stacking and discontinuous metamorphic gradients along the eastern margin of East Dharwar craton Indian Journal of Geology 80 173-188

Tripathy V and Saha D (2013) Plate margin paleostress variations and intracontinental deformations in the evolution of Cuddapah basin through the Proterozoic Precambrian Research 235 107-130

Tripathy V and Saha D (2015) Inversion of calcite twin data, paleostress reconstruction and multiphase weak deformation in the cratonic interior- evidence from the Proterozoic Cuddapah basin, India Journal of Structural Geology 77 62-81

Tripathy V, Satyapal Mitra S K and Sesha Sai V V (2019) FoldThrust Belt Architecture and Structural Evolution of the Northern Part of the Nallamalai Fold Belt, Cuddapah Basin, Andhra Pradesh, India In: Tectonics and Structural Geology: Indian Context (Ed: Mukherjee S) Springer Geology 219-252

Upadhyay D, Raith M M, Mezger K and Hammerschmidt K (2006) Mesoproterozoic rift-related alkaline magmatism at Elchuru, Prakasam alkaline province, SE India Lithos 89 $447-477$

Valdiya K S (2016) The making of India: Geodynamic Evolution. $2^{\text {nd }}$ Edn.Springer International, Switzerland 924

Vasudeva Rao M, Nagabhushana J C and Jeyagopal A V (1989) Uranium mineralization in the middle Proterozoic carbonate rocks of the Cuddapah Supergroup, southern Peninsular India Exploration and Research for Atomic Minerals 2 29-38

Venkatakrishna R and Dotiwala F E (1987) The Cuddapah salient: a tectonic model for the Cuddpah basin based on Landsat image interpretation Tectonophysics 136 447-477

Verma M B, Som A, Latha A, Umamaheswar K and Maithani P B (2008) Geochemistry of host granitoids of uranium deposit at Chitrial area, Srisailam Sub-basin, Nalgonda district, Andhra Pradesh Geological Society of India Memoir 73 $37-54$

Verma M B, Maithani P B, Chaki A, Nageshwar Rao P and Kumar P (2009) Province of unconformity-related deposits in Andhra Pradesh - case study of Chitrial uranium exploration, Nalgonda District Current Science 96 588591

Verma M B, Gupta S, Singh R V, Latha A, Maithani P B and Chaki A (2011) Ore body characterization of Koppunuru uranium deposit in Palnad Sub-basin, Guntur district, Andhra Pradesh Indian Mineralogist 45 51-61

Vijaya Kumar K, Ernst W G, Leelanandam C, Wooden J L and Grove M J (2010) First Paleoproterozoic ophiolite from Gondwana: geochronologic-geochemical documentation of ancient oceanic crust from Kandra, SE India Tectonophysics $48722-32$

Vimal R, Banerjee R, Gupta S, Krishna V, Achar K K, Ramesh Babu P V, Parihar P S and Maithani P B (2012) Geochemistry and $\mathrm{Sr}$ and $\mathrm{Pb}$ isotope systematics of basement granitoids from north and west of Palnad Sub- 
basin, Guntur and Nalgonda districts, Andhra Pradesh

Journal of Applied Geochemistry 14 295-315

Zachariah J K, Rao Y B, Srinivasan R and Gopalan K (1999) Pb, $\mathrm{Sr}$ and $\mathrm{Nd}$ isotope systematics of uranium mineralized stromatolitic dolomites from the Proterozoic Cuddapah Supergroup, south India: Constraints on age and provenance Chemical Geology 162 49-64

Zakaulla S, Umamaheshwar K, Tirupathi P V, Sharma U P, Basu H and Ali MA(2004) Geological and geochemical appraisal of uranium-bearing Gulcheru Formation of Cuddapah Supergroup, Gandi area, Cuddapah district, Andhra Pradesh Journal of the Geological Society of India 64 719730 . 